34 Keywords: Microbial abundance, Microbial biomass, Viruses, Bacteria, Protists, Zooplankton, 35 Time-series

\section{PLANKTONIC FOOD WEB STRUCTURE AT A COASTAL TIME-SERIES SITE: I. PARTITIONING OF MICROBIAL ABUNDANCES AND CARBON BIOMASS} David A. Caron ${ }^{\mathrm{a} *}$, Paige E. Connell ${ }^{\mathrm{a}}$, Rebecca A. Schaffner ${ }^{\mathrm{b}}$, Astrid Schnetzer ${ }^{\mathrm{c}}$, Jed A. Fuhrman ${ }^{\mathrm{a}}$, Peter D. Countway ${ }^{\mathrm{d}}$, Diane Y. Kim ${ }^{\mathrm{a}}$.

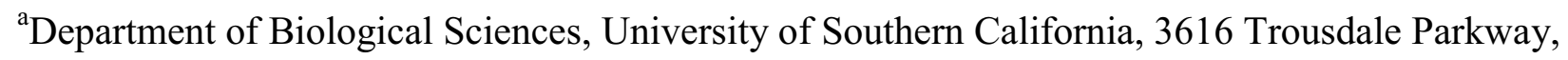
Los Angeles, CA 90089-0371 USA

${ }^{b}$ Maine Department of Environmental Protection, 17 State House Station, Augusta, Maine 04333-0017 USA

${ }^{c}$ Department of Marine, Earth and Atmospheric Sciences, North Carolina State University, Raleigh, NC 27695 USA

${ }^{\mathrm{d}}$ Bigelow Laboratory for Ocean Sciences, East Boothbay, ME 04544 USA

*Corresponding author: D.A. Caron, dcaron@usc.edu, Tel. +1 213 740-0203

E-mail addresses: dcaron@usc.edu (D.A. Caron), paigeeconn@gmail.com (P. Connell), Becky.Schaffner@maine.gov (R.A. Schaffner), aschnet@ncsu.edu (A. Schnetzer), fuhrman@usc.edu (J.A. Fuhrman), pcountway@bigelow.org (P.D. Countway), dianekim@usc.edu (D.Y. Kim). 
ABSTRACT

Biogeochemistry in marine plankton communities is strongly influenced by the activities of microbial species. Understanding the composition and dynamics of these assemblages is

40 essential for modeling emergent community-level processes, yet few studies have examined all

41 of the biological assemblages present in the plankton, and benchmark data of this sort from time-

42 series studies are rare. Abundance and biomass of the entire microbial assemblage and

43 mesozooplankton $(>200 \mu \mathrm{m})$ were determined vertically, monthly and seasonally over a 3-year

44 period at a coastal time-series station in the San Pedro Basin off the southwestern coast of the

45 USA. All compartments of the planktonic community were enumerated (viruses in the

46 femtoplankton size range [0.02-0.2 $\mu \mathrm{m}]$, bacteria + archaea and cyanobacteria in the

47 picoplankton size range [0.2-2.0 $\mu \mathrm{m}]$ phototrophic and heterotrophic protists in the

48 nanoplanktonic [2-20 $\mu \mathrm{m}]$ and microplanktonic [20-200 $\mu \mathrm{m}]$ size ranges, and mesozooplankton

$49[>200 \mu \mathrm{m}]$. Carbon biomass of each category was estimated using standard conversion factors.

50 Plankton abundances varied over seven orders of magnitude across all categories, and total

51 carbon biomass averaged approximately $60 \mu \mathrm{g} \mathrm{C}^{-1}$ in surface waters of the $890 \mathrm{~m}$ water column

52 over the study period. Bacteria + archaea comprised the single largest component of biomass

$53(>1 / 3$ of the total), with the sum of phototrophic protistan biomass making up a similar

54 proportion. Temporal variability at this subtropical station was not dramatic. Monthly depth-

55 specific and depth-integrated biomass varied 2-fold at the station, while seasonal variances were

56 generally $<50 \%$. This study provides benchmark information for investigating long-term

57 environmental forcing on the composition and dynamics of the microbes that dominate food web

58 structure and function at this coastal observatory. 


\section{Introduction}

The pivotal biogeochemical roles conducted by microbes in marine plankton communities

63 (herein defined as viruses, bacteria, archaea, phototrophic and heterotrophic microbial

64 eukaryotes) are now firmly entrenched in oceanographic paradigm (Calbet and Landry, 2004;

65 Calbet and Saiz, 2005; Sherr et al., 2007; Suttle, 2007; Fuhrman, 2009; Church et al., 2010;

66 Caron et al., 2012). Microbes are responsible for most of the primary production occurring in

67 pelagic communities, they dominate several trophic interactions near the base of the food web, conduct much of the carbon and nutrient cycling, and thereby affect the concentration and overall elemental stoichiometry of suspended particulate organic matter (Martiny et al., 2016). Yet, fundamental gaps and misconceptions persist in our understanding of the relative abundances, biomasses and activities of microbial assemblages, and their relationships to larger zooplankton. For example, controversy still exists as to whether community metabolism in major oceanic realms is net autotrophic or heterotrophic (Duarte et al., 2013; Ducklow and Doney, 2013; Williams et al., 2013).

These basic uncertainties relating to standing stocks and activities have important implications for how planktonic communities function, and how they might respond to changing water chemistry and physics that are anticipated over the next few centuries. Environmental change is expected to result in restructuring of pelagic food webs with significant implications for standing stocks of various plankton groups, their trophic relationships and emergent 80 properties of carbon utilization and energy flow (Samuelsson et al., 2002; McMahon et al.,

81 2015). However, our limited knowledge of the details of microbial community structure 82 constrains our ability to develop models that accurately predict ecosystem response. As a 83 consequence, Hood et al. (2006) noted that ecosystem models of increasing complexity have 84 often led to less, not more, predictive understanding of biological processes if the plankton 85 groups have not been adequately defined.

86 Predicting the activities of planktonic marine microbes is predicated on basic knowledge of 87 the distribution of biomass among the various taxonomic and functional assemblages that 88 comprise these communities because that information helps place constraints on rates of

89 production and turnover. The distribution of particulate organic carbon (POC) among the 90 various microbial assemblages is therefore of fundamental importance for modeling and 
91 predicting energy utilization and carbon flow in the plankton. Unfortunately, defining these 92 carbon budgets has been difficult. This situation is due, in part, to the fact that most studies of 93 planktonic microbial communities have focused only on specific components of the community

94 (often only the phytoplankton or bacteria) and, in part, because of uncertainties associated with 95 converting cell abundances to standing stocks of carbon or major nutrients. Obtaining more 96 complete data of microbial abundances has been addressed by the development and application 97 of a suite of methodologies that now allow relatively thorough characterization of all major 98 groups of microbes in a sample, yet conversion to biomass remains problematic.

99 Most past studies that have reported abundances and biomass across many microbial taxa 100 have been conducted on plankton communities of open ocean environments, and often within the 101 context of major oceanographic programs such as the Joint Global Ocean Flux Study (JGOFS) or 102 in conjunction with oceanic time series stations (Caron et al., 1995; Roman et al., 1995; Buck et 103 al., 1996; Stoecker et al., 1996; Garrison et al., 2000; Dennett et al., 2001; Steinberg et al., 2001; 104 Brown et al., 2003; Church et al., 2010; Karl and Church, 2014). Reports prior to the mid-1990s 105 did not include viruses whose potentially important contribution to POC was not yet realized, or 106 the contribution of mesozooplankton in some cases. Those studies clearly demonstrated the 107 considerable contribution of heterotrophic microbes to the total standing stock of living biomass 108 in the plankton, and in particular the importance of heterotrophic bacteria (including bacteria + 109 archaea; henceforth referred to as 'bacteria'). However, studies examining the distribution of 110 plankton biomass among the various microbial taxonomic groups are rare from coastal 111 ecosystems because such analyses have not been a priority for most coastal studies.

112 Nevertheless, these regions can be important sinks for atmospheric carbon dioxide (Hales et al., 113 2005), and it is therefore imperative to fully characterize and understand the abundances, 114 biomasses and activities of the plankton assemblages in these regions.

115 A 3-year dataset of microbial abundances and biomass, and supporting chemical/physical 116 data collected at the San Pedro Ocean Time-series (SPOT) site off southern California, USA, 117 was analyzed in order to determine and compare the monthly and seasonal variability in standing 118 stocks of various planktonic taxonomic groups (viruses to mesozooplankton). Previous studies 119 conducted at the site have documented vertical, monthly, seasonal, annual and interannual 120 changes in species richness and community composition of the microbial assemblages, as well as 121 trophic relationships and associations among these microbial groups (Fuhrman et al., 2009; 
122 Schnetzer et al., 2011; Steele et al., 2011; Chow and Fuhrman, 2012; Chow et al., 2013; Kim et

123 al., 2013; Chow et al., 2014; Cram et al., 2014). The present study was conducted to provide

124 these investigations with contextual information on the overall abundances and biomasses of the

125 various microbial groups, and a framework for examining trophic interactions and carbon flow

126 through this planktonic community (Connell et al., In review).

127 Summed across all years and months, integrated microbial biomass in the upper $100 \mathrm{~m}$ of the 128 water column was approximately $4 \mathrm{~g} \mathrm{C} \mathrm{m}^{-2}$, with heterotrophs constituting approximately half of 129 that biomass (predominantly bacteria, but also significant contributions of heterotrophic protists).

130 Minute $(<2 \mu \mathrm{m})$ cyanobacteria and eukaryotic algae generally dominated the biomass of

131 phototrophs in the euphotic zone where they were approximately one quarter of the total

132 microbial biomass, but diatoms were seasonally important. Mesozooplankton contributed a

133 minor overall component to total plankton biomass ( $\approx 0$ to a maximum of $<10 \%$ seasonally).

\section{Materials and methods}

\subsection{Study area, environmental parameters}

The San Pedro Ocean Time-series (SPOT) site is situated centrally in the San Pedro Basin approximately $15 \mathrm{~km}$ from the coast of southern California $\left(33^{\circ} 33^{\prime} \mathrm{N} ; 118^{\circ} 24^{\prime} \mathrm{W}\right)$, USA,

141 between the highly urbanized region of greater Los Angeles and the relatively undeveloped

142 Santa Catalina Island (Fig. 1). The basin has a water depth at the sampling site of $\approx 890 \mathrm{~m}$, and

143 sills occur to the east and west at water depths of approximately 740 and $650 \mathrm{~m}$, respectively.

144 Water flow through the basin is limited by this bottom topography, and the water column below 145 approximately $300 \mathrm{~m}$ persistently experiences $<1 \mathrm{ml}^{-1}$ oxygen.

146 Water column sampling and chemical/physical measurements were conducted aboard the $147 \mathrm{R} / \mathrm{V}$ Sea Watch using a rosette sampler equipped with an array of sensors and Niskin bottles for 148 water collection. Samples and water column properties were collected approximately monthly as 149 a part of the San Pedro Oceanographic Time-series Program. Details and chemical/physical data 150 are available through the SPOT website (http://dornsife.usc.edu/spot/ctd-data/). Measurements 151 of temperature and depth were accomplished with a Sea-bird Electronics or SBE 911 plus CTD 152 (Sea-Bird Electronics, Inc., Bellevue, WA, USA), in situ chlorophyll fluorescence was measured 
using a Wet Labs WETStar fluorometer (WETLabs, Philomath, OR, USA) or Seapoint

154 fluorometer (Seapoint Sensors, Inc., Exeter, NH, USA) and dissolved oxygen was measured with a SBE 13 sensor (Sea-Bird Electronics, Inc.), attached to the water-sampling rosette.

156 Measurements of dissolved oxygen and nutrients (nitrate, nitrite, phosphate and silicate) were 157 obtained from samples collected in Niskin bottles on the rosette. Samples were generally 158 collected and processed from 12 depths in the upper $500 \mathrm{~m}$. Dissolved oxygen concentrations 159 were measured by Winkler titration (Grasshoff et al., 2007), while nutrient concentrations were 160 measured using an Alpkem RFA Auto Analyzer (Alpkem Corporation, Clackamas, OR) using standard protocols (Gordon et al., 1993). The latter measurements were performed by SPOT

162 personnel and are available through the SPOT website. Mixed-layer depths (MLDs) of the water 163 column were defined and calculated for each cruise as in Kim et al. (2013), as the depths at 164 which $\sigma_{\theta}$ (potential density) differed from surface water $(10 \mathrm{~m}) \sigma_{\theta}$ by $0.125 \mathrm{~kg} \mathrm{~m}^{-3}$ (Levitus, 165 1982).

\subsection{Collecting and counting plankton assemblages}

A three-year dataset (2000-2003) of monthly samples collected at four depths was analyzed for all components of the microbial planktonic community (viruses to protistan microplankton),

172 for mesozooplankton (metazoan $>200 \mu \mathrm{m}$ ). Water samples from the Niskin bottles were

173 processed for the determination of abundances of viruses, heterotrophic bacteria (including

174 bacteria + archaea; henceforth referred to as 'bacteria'), coccoid cyanobacteria (Synechococcus

175 spp. and Prochlorococcus spp.), phototrophic picoeukaryotes (eukaryotic algae $<2 \mu \mathrm{m}$ ),

176 phototrophic (including mixotrophic) and heterotrophic nanoplankton $(2-20 \mu \mathrm{m})$, phototrophic

177 and heterotrophic microplankton $(20-200 \mu \mathrm{m})$. Sampling depths for determinations of microbial

178 abundances and biomass were $5 \mathrm{~m}$, the depth of the subsurface maximum in chlorophyll

179 concentration (Subsurface Chlorophyll Maximum [SCM], a persistent feature at the SPOT

180 station), $150 \mathrm{~m}$ and $500 \mathrm{~m}$. The depth of the SCM was determined on each cruise from real-time

181 chlorophyll fluorescence detected during the vertical profiling with the sampling rosette.

182 Chlorophyll $a$ concentrations from $5 \mathrm{~m}$ and the SCM were measured on discrete samples

183 collected at these depths and filtered onto GF/F Whatman filters, extracted in 90\% acetone for 24 
$184 \mathrm{~h}$ at $-20^{\circ} \mathrm{C}$, and analyzed by standard fluorometric procedures (Parsons et al., 1984).

185 Samples for virus counts were collected and preserved with $0.02 \mu \mathrm{m}$ filtered $2 \%$ formalin.

186 Viruses were visualized by staining with SYBR Green I (Molecular Probes-Invitrogen) and

187 counted by epifluorescence microscopy (Noble and Fuhrman, 1998). Samples for the

188 enumeration of heterotrophic bacteria, Synechococcus spp., Prochlorococcus spp. and

189 phototrophic picoeukaryotes were preserved with $1 \%$ filtered formalin and stored frozen at $-80^{\circ} \mathrm{C}$

190 until analyzed by flow cytometry. Flow cytometry was conducted using a FACSCalibur flow

191 cytometer (Becton Dickinson). Cyanobacteria and picoplanktonic eukaryotic algae were

192 detected by the autofluorescence of photosynthetic pigments and forward scatter, while bacterial

193 abundances were determined by staining samples with SYTO 13 to visualize them and counted

194 using a routine protocol by flow cytometry (del Giorgio et al., 1996).

195 Samples $(100 \mathrm{ml})$ for nanoplankton counts (phototrophic and heterotrophic protists 2-20 $\mu \mathrm{m}$

196 in size) were preserved with $1 \%$ filtered formalin and stored at $4^{\circ}$ in the dark until processing

197 (generally within $24 \mathrm{hrs}$ ). Subsamples of 25-50 ml were stained with 4',6-diamidino-2-

198 phenylindole (DAPI; $25 \mathrm{mg} \mathrm{ml}^{-1}$ final concentration), filtered onto 0.8 - $\mu \mathrm{m}$ black polycarbonate

199 filters and counted by epifluorescence microscopy using standard methods (Sherr et al., 1993).

200 Phototrophic and heterotrophic forms were distinguished based on the presence or absence of

201 chlorophyll autofluorescence. Mixotrophic forms (phagotrophic phytoflagellates capable of

202 ingesting prey) were not distinguished and therefore were included in the counts of phototrophic

203 nanoplankton (Sanders and Porter, 1988). Microplankton (predominantly protists 20-200 $\mu \mathrm{m}$ in

204 size) were preserved with 10\% Lugol's solution (250 $\mathrm{ml}$ in amber glass bottles, and stored in a

205 cool darkened room until counted), and counted by settling 80-100 ml subsamples in settling

206 chambers and analyzing by inverted light microscopy. Lugol's solution allowed better

207 visualization and enumeration of some taxa (Utermöhl, 1958). Dinoflagellates were not

208 distinguished as phototrophs or heterotrophs in the microscopical counts because Lugol's

209 solution masks the autofluorescence of chlorophyll. Additionally, as a group, dinoflagellate

210 nutrition is complex including obligate heterotrophs, phototrophs and many mixotrophs. A

211 detailed taxonomic characterization of the dinoflagellates was beyond the scope of this study and

212 therefore half of the dinoflagellates were assumed to be phototrophic and half were assumed to

213 be heterotrophic (Sherr and Sherr, 2007). Distinctions among major groups of microplankton 
214 (diatoms, dinoflagellates, ciliates) were made at 200x or 400x magnification on an inverted 215 microscope.

216 Mesozooplankton samples (metazoa $>200 \mu \mathrm{m}$ ) were collected using a $50 \mathrm{~cm}$ diameter 200 $217 \mu \mathrm{m}$ mesh, Sea-Gear ${ }^{\circledR}$ model 9000 plankton net. Oblique tows in the top $100 \mathrm{~m}$ of the water 218 column were conducted. Nets were towed at $\approx 30 \mathrm{~cm}$ per second, continuously lowered and 219 raised to provide a single depth-integrated sample. The volume filtered was estimated using a

220 Sea-Gear mechanical impeller flow meter calibrated according to the manufacturers

221 specifications. All tows were conducted during daylight hours (10:00-14:00 hr). Total

222 zooplankton displacement volume was determined for each sample from the net tow material

223 using standard protocols (Wiebe et al., 1975), and major taxonomic groups of zooplankton were

224 determined using a dissecting microscope.

\subsection{Estimating biomass of plankton assemblages}

Abundances of each plankton assemblage described above were converted to particulate organic carbon (POC) using approaches and conversion factors chosen from the literature that

230 were representative of coastal ocean microbes Table 1). Viruses were converted assuming an 231 average value of $0.2 \mathrm{fg} \mathrm{C}$ virus $^{-1}$ (Kepner et al., 1998; Suttle, 2005). Bacteria were converted

232 directly from cell abundances based on a value of $15 \mathrm{fg} \mathrm{C}$ cell ${ }^{-1}$. This value is at the lower end of 233 values derived for coastal regions but higher than some values for oceanic ecosystems (Fukuda et 234 al., 1998; Kawasaki et al., 2011; Buitenhuis et al., 2012). Cyanobacteria (Synechococcus and 235 Prochlorococcus) were converted to POC assuming values of $200 \mathrm{fg} \mathrm{C}^{-1 l^{-1}}$ and $90 \mathrm{fg} \mathrm{C}$ cell $^{-1}$, 236 respectively (Buitenhuis et al., 2012; Martiny et al., 2016). Phototrophic picoeukaryote 237 abundances were converted assuming an average cell diameter of $2 \mu \mathrm{m}$, and converting cell

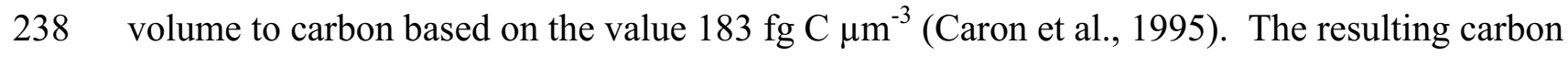
239 content is within the range but at the lower end of published values for this assemblage 240 (Buitenhuis et al., 2012; Casey et al., 2013). Our flow cytometric counting approach for 241 phototrophic picoeukaryotes $(<2 \mu \mathrm{m})$ were designed to minimize overlap with microscopical 242 counts of nanoplankton, the latter were converted assuming an average cell diameter of $3 \mu \mathrm{m}$ and

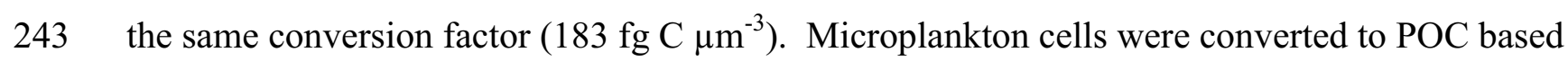
244 on a constrained conversion value (138 $\mathrm{pg} \mathrm{C} \mathrm{cell}^{-1}$ ) derived by Caron et al. (Caron et al., 1995). 
245 Mesozooplankton displacement volumes (Wiebe et al., 1975) were converted to POC based on a 246 conversion factor of $21 \mathrm{mg} \mathrm{C} \mathrm{ml}^{-1}$, representative of a mixed zooplankton assemblage (Bode et 247 al., 1998; Harris et al., 2000).

248 Depth-integrated carbon biomass of the plankton community $(0-100 \mathrm{~m}$ and $0-500 \mathrm{~m})$ was 249 obtained from the biomass measured at each of the four depths multiplied by the interpolated 250 depth ranges between the sampling depths. Depth ranges between the $5 \mathrm{~m}$ and SCM, and the 251 SCM and $150 \mathrm{~m}$ varied due to the variability of the depth of the SCM. Integrated biomass values

252 between the surface and $500 \mathrm{~m}$ were estimated as the sum of biomass in each depth interval (as 253 POC $\left.\mathrm{m}^{-2}\right)$ using the following equation: [(5+(SCM-5)/2) $\mathrm{x}(5 \mathrm{~m}$ biomass values $\left.)\right]+[((\mathrm{SCM}-$

$2545) / 2+(150-\mathrm{SCM}) / 2) \times(\mathrm{SCM}$ biomass values $)]+[((150-\mathrm{SCM}) / 2+(500-150) / 2) \times(150 \mathrm{~m}$ biomass 255 values $)]+[((500-150) / 2) \times(500 \mathrm{~m}$ biomass values $)]$. Integrated biomass values between the 256 surface and $100 \mathrm{~m}$ were estimated as follows: [(5+(SCM-5)/2) $\times(5 \mathrm{~m}$ biomass values $)]+[((\mathrm{SCM}-$

$2575) / 2+(150-\mathrm{SCM}) / 2) \mathrm{x}(\mathrm{SCM}$ biomass values $)]+[(100-((5+(\mathrm{SCM}-5) / 2)+(\mathrm{SCM}-5) / 2+(150-$ $258 \mathrm{SCM} / 2)) \mathrm{x}(150 \mathrm{~m}$ biomass values $)]$.

259 Monthly averages of carbon biomass were determined from values in each month collected 260 throughout the three-year study. Seasonal averages were then determined for the months 261 December-February (winter), March-May (spring), June-August (summer) and September262 November (fall).

\section{3. Results}

\subsection{Hydrography and oceanographic context}

The hydrography and environmental parameters at our study site in the central San Pedro

270 Collins et al., 2011; Hamersley et al., 2011; Schnetzer et al., 2011; Chow and Fuhrman, 2012;

271 Kim et al., 2013; Cram et al., 2014). Representative vertical profiles of pertinent parameters

272 from four seasons during this study illustrate a persistently-stratified water column with

273 considerable vertical structure (Fig. 2). Seasonal temperatures at the surface fluctuated

274 approximately $5-6^{\circ} \mathrm{C}$, with a typical seasonal low of $14^{\circ} \mathrm{C}$ and a seasonal high of $19-20^{\circ} \mathrm{C}$ (Fig.

275 2a). Water temperature below approximately $40 \mathrm{~m}$ decreased from 11 to $\approx 6^{\circ} \mathrm{C}$ at $500 \mathrm{~m}$ 
276 regardless of season (inset in Fig. 2a). A similar pattern of decreasing concentrations of 277 dissolved oxygen with depth was observed, although oxygen decreased more gradually than

278 temperature (Fig. 2b). Water at our sampling depth of $500 \mathrm{~m}$ contained persistently low 279 concentrations of dissolved oxygen $\left(<1 \mathrm{ml} \mathrm{l}^{-1}\right)$, indicative of restricted flow into and out of the

280 basin. Our sampling depth of $150 \mathrm{~m}$ exhibited dissolved oxygen concentrations that were 281 relatively constant at approximately half surface values.

282 Nutrient patterns indicated that productivity in surface waters at the study site were typically 283 and consistently N-limited (Fig. 2c-f). Nitrate was near or below the analytical limit of detection 284 at all seasons, although nitrite showed a pronounced peak in concentration at approximately 40 $285 \mathrm{~m}$ (within the region of rapidly decreasing dissolved oxygen concentrations). Phosphate and 286 silicate concentrations were substantially lower in surface waters than at depth, but were 287 generally detectable in all seasons (insets in Fig. 2e,f).

288 Monthly changes in the average mixed layer depth during the three-year study indicated a 289 relatively shallow mixed layer throughout much of the year at the SPOT study site (Fig. 3).

290 Mixed layers in spring through fall were generally $<20 \mathrm{~m}$, while mixed layers during the winter 291 occasionally exceeded $40 \mathrm{~m}$. The year round persistence of well-defined mixed layers is 292 indicative of the subtropical climate of the region.

293 The existence of a relatively shallow mixed layer throughout the year at the SPOT site 294 resulted in the development and maintenance of a modest but persistent subsurface maximum in 295 chlorophyll concentration (Subsurface Chlorophyll Maximum: SCM) that always equaled or 296 exceeded chlorophyll concentrations observed near the surface, with the exception of September 2972002 (Fig. 4). The depth and magnitude of the SCM varied seasonally but rarely exceeded $\approx 2 \mu \mathrm{g}$

$298 \mathrm{I}^{-1}$ throughout the three-year study period. Differences in chlorophyll concentrations between the 299 two depths were typically more pronounced during summer months than winter. This pattern is 300 consistent with trends observed at the sampling site across a 10-year period (Chow et al., 2013; 301 Kim et al., 2013).

\subsection{Microbial abundances at the San Pedro Ocean Time-series station}

Abundances of the various microbial assemblages observed at four depths in the water column at the SPOT study site varied by seven orders of magnitude (Table 1). Viral particles 
307 were the most abundant assemblage, exceedingly $10^{7}$ particles $\mathrm{ml}^{-1}$ in surface waters, with 308 abundances approximately one order of magnitude lower at $500 \mathrm{~m}$. Bacteria were approximately

309 10-fold less abundant than viruses (average $\approx 2 \times 10^{6} \mathrm{ml}^{-1}$ in the mixed layer) and also decreased 310 one order of magnitude with depth. Abundances of coccoid cyanobacteria (Synechococcus spp. 311 and Prochlorococcus spp.) were $\approx 1-3 \times 10^{4} \mathrm{ml}^{-1}$ in mixed layer samples, with Synechococcus 312 generally twice as abundant as Prochlorococcus, while phototrophic picoeukaryotic algae were 313 2-3-fold less abundant than cyanobacteria (averages of $\approx 0.9-1 \times 10^{4} \mathrm{ml}^{-1}$ ). These three latter 314 phototrophic assemblages were largely relegated to samples collected at $5 \mathrm{~m}$ and the SCM 315 (values were $>2$ orders of magnitude lower at 150 and $500 \mathrm{~m}$ ).

316 Protists $>2 \mu \mathrm{m}$ in size occurred at significantly lower abundances than prokaryotic 317 assemblages. Phototrophic/mixotrophic and heterotrophic nanoplankton (P/MNANO and 318 HNANO) occurred at average abundances of $0.8-3 \times 10^{3} \mathrm{ml}^{-1}$ in samples from the mixed layer, 319 with HNANO abundances generally 2-3X the abundances of P/MNANO. P/MNANO 320 abundances decreased precipitously with depth, while decreases in HNANO were $>10$-fold. 321 Microplanktonic protists ( $>20 \mu \mathrm{m}$ in size; predominantly ciliates, dinoflagellates and diatoms)

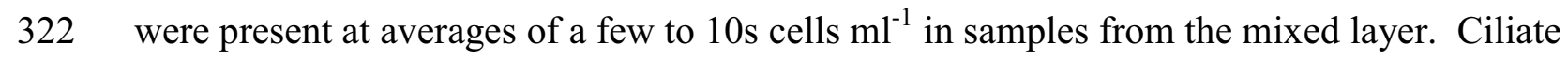
323 abundances were $>10$-fold lower in deep samples at the site, while dinoflagellates and diatoms at 324150 and $500 \mathrm{~m}$ only decreased by approximately half their abundances relative to samples from 325 the mixed layer. The presence of dinoflagellates in deep waters at the SPOT site may reflect 326 shifts in species composition of this assemblage from phototrophic to heterotrophic taxa, while 327 the existence of diatoms in deep samples presumably reflected rapid sinking of these 328 phototrophic cells from surface waters (Schnetzer et al., 2007).

329 All of the microbial assemblages varied with sampling season (note ranges in abundances in 330 Table 1 below mean values). These variances in abundance were reflected in their contributions 331 to overall microbial biomass at the study site (see below).

\subsection{Total microbial biomass}

The large differences in microbial abundances observed at the SPOT site were dramatically reduced when the biomass of each assemblage was estimated from cell abundances and appropriate conversion factors (Fig. 5). Integration of microbial biomass to $100 \mathrm{~m}$ was used 
because it approximates the lower-most extent of the seasonally-independent thermocline and nutricline, and therefore represents a reasonable approximation of plankton standing stocks in the water column directly influenced by near-surface processes (Fig. 2, and data not shown). Bacteria constituted nearly one third of the total microbial biomass when integrated throughout the top $100 \mathrm{~m}$ of the water column (Fig. 5a), and made a somewhat larger contribution to total biomass when integrated over $500 \mathrm{~m}$ due to reduced contributions by most phototrophic components (Fig. 5b). Phototrophic prokaryotes (Synechococcus and Prochlorococcus) and eukaryote algae $<2 \mu \mathrm{m}$ in size comprised approximately one quarter of the microbial biomass in the top $100 \mathrm{~m}$, but only half that value when biomass was integrated for the upper $500 \mathrm{~m}$.

All protists (pico-, nano- and microplanktonic phototrophs and heterotrophs) totaled $>40 \%$ of the microbial biomass at the SPOT site, and were very similar for the two depth integrations (Fig. 5a,b). Reductions in the contributions of phototrophic picoeukaryote and P/MNANO assemblages in the $0-500 \mathrm{~m}$ integration relative to the $0-100 \mathrm{~m}$ integration were offset by greater relative contributions of dinoflagellates and diatoms in deep samples.

Despite their numerical dominance in the water column relative to all other microbial assemblages (Table 1), viruses comprised $<10 \%$ of total microbial biomass, and their contribution was relatively unchanged for the 0-100 and 0-500 $\mathrm{m}$ depth integrations (Fig. 5a,b).

355 Depth-integrated biomass of all microbial assemblages in the top $100 \mathrm{~m}$ of the water column was

$356 \approx 4 \mathrm{~g} \mathrm{C} \mathrm{m}^{-2}$, approximately half the biomass estimated in the top $500 \mathrm{~m}$ of the water column Fig. $3575 \mathrm{c})$.

358 Carbon-to-chlorophyll ratios (C:Chl: by mass) were calculated for samples obtained from 5 $359 \mathrm{~m}$ and the SCM using carbon values estimated from cell abundances for phototrophic 360 assemblages and their group-specific conversion values, and chlorophyll values measured 361 fluorometrically in the same samples. C:Chl ratios were calculated using the combined biomass 362 of the cyanobacteria, phototrophic picoeukaryotes, P/MNANO, and microplanktonic 363 phototrophs; Fig. 6). These ratios provide a degree of evaluation of the conversion factors used 364 to estimate organic carbon for phototrophic microbial groups (see Materials and methods; also 365 see (Caron et al., 1995) for reasoning). Ratios obtained for samples analyzed in the study were 366 highly variable (Fig. 6). The average C:Chl ratio for samples collected at 5m was 57, while 367 samples collected at the SCM yielded an average C:Chl of 34. These averages are well within 
the range of values reported in the literature for surface-dwelling and low-light adapted phytoplankton assemblages, respectively.

\subsection{Vertical and seasonal variances in microbial biomass}

The vertical distribution of microbial biomass at the SPOT site reflected absolute reductions in the biomass of all microbial assemblages with depth (Fig. 7). Total microbial biomass ranged from nearly $60 \mu \mathrm{g} \mathrm{C}^{-1}$ at $5 \mathrm{~m}$ to $<10 \mu \mathrm{g} \mathrm{C}^{-1}$ at $500 \mathrm{~m}$. Contributions of the various assemblages to microbial biomass were relatively consistent for samples from $5 \mathrm{~m}$ and the SCM, as well as for samples from 150 and $500 \mathrm{~m}$, but samples from the upper water column had more than 5 times greater biomass than the two deep samples (Fig. 7). Seasonal fluctuations in the vertical distribution of microbial biomass were not dramatic (Fig. 8). Values at $5 \mathrm{~m}$ and the SCM observed during spring and summer were greater than values observed at those depths during winter and fall (Fig. 8b,c vs. 8a,d, respectively), but only modestly so (approximately $40 \%$ greater). Biomass at 150 and $500 \mathrm{~m}$ remained relatively unchanged seasonally.

Microbial biomass estimated for samples collected at $5 \mathrm{~m}$ and the SCM averaged over the three-year study period exhibited more variability monthly (Fig. 9a,b) than seasonally (Fig. 10a,b). A similar relationship was observed for depth-integrated microbial biomass (Fig. 9c,d vs. $10 \mathrm{c}, \mathrm{d})$. Monthly values varied as much as $2-3 \mathrm{X}$ while seasonal averages varied by $30-40 \%$. Among the monthly estimations, April (with one exception) was generally a period of particularly high standing stocks of microbial biomass (Fig. 9).

\subsection{Mesozooplankton contribution to plankton community biomass}

The contribution of mesozooplankton biomass, estimated directly from measurements of displacement volume for two years of monthly samples, revealed a single large peak in biomass

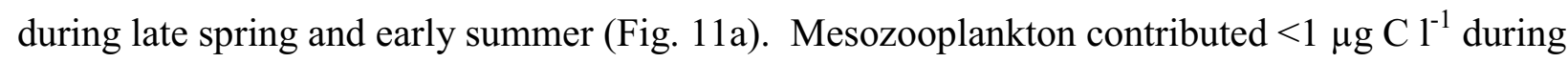
late winter, and a maximum of $6.3 \mu \mathrm{g} \mathrm{Cl}^{-1}$ at peak contribution. Qualitative information on the composition of the mesozooplankton assemblage was obtained by microscopy on these samples. All samples were strongly dominated by crustaceans (predominantly calanoid copepods) numerically, and copepods also contributed a dominant fraction of the total displacement 
volumes. Appendicularia, chaetognaths and small cnidaria made minor but relatively consistent contributions.

401 Mesozooplankton biomass always constituted a minor component of total biomass when 402 compared to either microbial prokaryotic or microbial protistan biomass (Fig. 11b), although 403 mesozooplankton may have been underestimated in this study because all net tows were 404 performed during the day, and therefore did not assess the importance of nighttime vertical 405 migrators. Only in one sample, when mesozooplankton biomass was maximal (June) did these 406 species contribute $10 \%$ of the total microbial biomass.

\section{Discussion}

Climate change is expected to alter water column physics and chemistry of coastal

412 food web structure and function in many locations is still being debated (Sydeman et al., 2014),

413 but the impact of shifting climate has already been documented for important fisheries species at

414 the top of some marine food webs (Cheung et al., 2013). The consequences of such

415 environmental change on planktonic assemblages comprising the base of the food web are less

416 well characterized but are essential for understanding how climate change will affect energy

417 production and overall food web structure (Hofmann et al., 2013).

418 Towards this end, benchmark information derived from long-term marine observing

419 programs in oceanic realms have provided unique perspectives on the multi-decadal response of

420 pelagic oceanic communities and biogeochemical processes to climatological forcing (Karl and

421 Michaels, 1996; Steinberg et al., 2001; Karl and Church, 2014). Time-series observatories in

422 coastal ecosystems have more recently begun to contribute insight (Alber et al., 2013). For

423 example, analysis of satellite data along the west coast of the U.S. has indicated that

424 phytoplankton standing stocks within the California Current System, and more locally

425 phytoplankton bloom events within the Southern California Bight, increased during the period

426 1997-2007 (Kahru et al., 2009; Nezlin et al., 2012). Conversely, analysis of a multi-decadal

427 time-series of zooplankton throughout the California Cooperative Oceanic Fisheries

428 Investigation grid (CalCOFI) indicated a decline in zooplankton displacement volume that was

429 attributed to decreasing abundances of pelagic tunicates (Lavaniegos and Ohman, 2007). Such 
430 changes may be due to influences on upwelling frequency or severity (Aksnes and Ohman, 2009;

431 Rykaczewski and Dunne, 2010), since coastal upwelling appears to be the primary driver of

432 production in the Bight region. Additionally, the contribution of high-nutrient effluent discharge

433 from Publicly Owned Treatment Works (POTWs) may be significant on smaller, local temporal

434 and spatial scales (Kudela et al., 2005; Howard et al., 2014). Whether these shifts in system

435 productivity represent normal decadal-scale oscillations or anthropogenic effects (either large-

436 scale climatic shifts or local changes in coastal development) is unclear. The lifespans of many

437 coastal observatories are still relatively short and often include a limited number of biological

438 measurements, and are therefore just beginning to provide insight into the long-term

439 responsiveness of these productive and highly utilized (and often impacted) areas of the ocean.

440 The San Pedro Ocean Time-series has been the site of monthly measurements of ocean

441 chemistry and physics for nearly twenty years. The site has also been the location of fairly

442 extensive observations of microbial oceanography as part of a National Science Foundation

443 Microbial Observatory beginning in 2000, and more recently a NSF Dimensions of Biodiversity

444 project. These programs have supported measurements of planktonic microbial diversity

445 (viruses, archaea, bacteria, microbial eukaryotes), and together constitute one of the longest time

446 series of microbial oceanography at a coastal site. This study presents an analysis of the

447 abundances and standing stocks of biomass of these various microbial assemblages for this site.

\subsection{Constraining conversion factors and estimating depth-integrated biomass}

The construction of models summarizing microbial biomass and energy flow in pelagic ecosystems is dependent on the ability to count all planktonic microbial groups (viruses, bacteria, 453 etc.), converting cell abundances or cell volumes to carbon biomass (Anderson and Ducklow, 454 2001), and summing biomass across all groups within the water column. By far, the largest 455 uncertainty in the methodologies applied to derive living biomass in natural microbial 456 communities lies in the conversion factors employed to conduct these studies. While our 457 knowledge of the diversity of planktonic microbes and methods for enumerating them in natural 458 communities have improved significantly in recent years, estimates of their contributions to 459 particulate organic carbon are still affected by often-poorly-constrained conversion factors. 460 Unfortunately, empirical determination of these factors for all plankton compartments in the 
461 present study was not realistic, therefore we chose relatively conservative conversion factors to 462 avoid overestimating microbial biomass. Nonetheless, over- or underestimation may have 463 occurred for one or more of the categories examined.

464 The conversion of bacterial abundances to POC is probably the most poorly constrained 465 parameter when estimating microbial biomass in the plankton. This situation exists because 466 bacterial cell volume is highly variable with taxonomic composition of the assemblage and 467 metabolic state (and very difficult to measure directly), and also because bacteria generally 468 constitute the largest single compartment of living microbial biomass in the plankton within 469 many aquatic ecosystems including the SPOT site (e.g. Fig. 5, 7, 8). A recent review of bacterial 470 conversion factors indicated an overall range of two orders of magnitude; 2 to $260 \mathrm{fg} \mathrm{C}$ cell $^{-1}$ 471 (Kawasaki et al., 2011). These authors used a value of $6.3 \mathrm{fg} \mathrm{C}^{-1 l^{-1}}$ to estimate the amount of 472 living carbon in the bacterial assemblage at Station ALOHA in the oligotrophic North Pacific 473 gyre, and noted that the choice of conversion factor significantly affected estimates of the 474 standing stock of bacteria in oceanic regions (nearly 6-fold; see Table 4 in Kawasaki et al. 2011). 475 A global inventory of oceanic bacterial biomass by Buitenhuis et al. (2010) employed a value of $4769.1 \mathrm{fg} \mathrm{C}^{-1}$ cell $^{-1}$. The authors reported that bacterial carbon biomass in much of the world ocean 477 was in the range $10-20 \mu \mathrm{g} \mathrm{C}^{-1}$. These latter values are in line with estimates of bacterial 478 biomass observed in the present study $\left(\approx 20 \mu \mathrm{g} \mathrm{C}^{-1}\right.$ in samples from the upper water column; 479 Fig. 5a,b, 7, 8).

480 The conversion factors employed in the studies described above are appropriate for oceanic 481 bacterial assemblages, but carbon cell ${ }^{-1}$ derived for coastal communities of bacteria have 482 typically been much greater than values applied to oceanic environments (Lee and Fuhrman, 483 1987; Cho and Azam, 1990; Fukuda et al., 1998; Kawasaki et al., 2011). The value of 15 fg C 484 cell $^{-1}$ employed in the present study is on the low end of cellular carbon content reported for 485 coastal marine bacteria, so should represent a reasonably conservative estimate of the 486 contribution of bacteria to total microbial biomass. Our conversion factor is slightly higher than 487 a value $\left(11 \mathrm{fg} \mathrm{C} \mathrm{cell}^{-1}\right)$ used to estimate bacterial carbon in the Southern California Current 488 System offshore from our study site (Taylor et al., 2015), and therefore seemed appropriate for 489 our coastal station at the edge of that hydrographic region. Use of $11 \mathrm{fg} \mathrm{C}^{-1} \mathrm{cel}^{-1}$ for bacteria at 490 the SPOT station would reduce our estimated contribution of bacterial biomass in total microbial 491 carbon in the water column from approximately $40 \%$ to approximately $30 \%$ (Fig. 5a,b). That 
492 estimate would still constitute a dominant component of the living microbial biomass at our

493 study site, but it also indicates the critical nature of one's choice of conversion factor.

494 Unfortunately, factors for converting bacterial abundance to carbon have not become more

495 accurately defined over the last two decades, and therefore they probably comprise the largest

496 single source of uncertainty in estimating living microbial biomass in natural samples.

497 Conversion factors reported for picoplanktonic phototrophs (Synechococcus spp.,

498 Prochlorococcus spp., phototrophic picoeukaryotes) are also variable, but not to the degree

499 reported for bacteria. The conversion factor that we employed for phototrophic picoeukaryotes

$500 \quad\left(\approx 770 \mathrm{fg} \mathrm{C}\right.$ cell $\left.^{-1}\right)$ represented a conservative estimate for this assemblage based on recent

501 summaries of these values (Buitenhuis et al., 2012; Casey et al., 2013). Similarly, we employed

502 conversion factors for Synechococcus and Prochlorococcus (200 and $90 \mathrm{fg} \mathrm{C}^{\mathrm{C}} \mathrm{ll}^{-1}$, respectively)

503 based on recent reviews of these values (Buitenhuis et al., 2012; Casey et al., 2013) because

504 routine cell sizing was beyond the scope of our study. Our value for Synechococcus was an

505 approximate average of the range presented in those reviews, while our conversion factor for

506 Prochlorococcus was based on larger cell sizes reported in Velduis et al. (Veldhuis et al., 1997).

507 Based on our conversion factors, phototrophic picoeukaryotes at our study site contributed a

508 biomass generally equal to or exceeding the biomass of the two cyanobacterial groups (Fig. 5, 7-

509 10). Collectively, the three assemblages averaged approximately $12 \mu \mathrm{g} \mathrm{Cl}^{-1}$ in the upper water

510 column $(\approx 20 \%$ of total microbial biomass; Fig. 7$)$. Analysis of these three plankton assemblages

511 in the lower Southern California Bight, using somewhat lower conversion values than our study,

512 yielded carbon biomass values that were very similar to our estimates (Worden et al., 2004).

513 Synechococcus biomass in the present study exceeded that of Prochlorococcus by

514 approximately a factor of four (Fig. 5a). A similar result was reported by Worden et al. (2004).

515 However, genetic studies of cyanobacterial diversity conducted at the SPOT site have shown that

516 Prochlorococcus sequences are more common than Synechococcus sequences in environmental

517 sequence datasets (Chow et al., 2013). That mismatch may be a consequence of an

518 underestimation of the abundances of weakly fluorescent Prochlorococcus cells by our flow

519 cytometric method, or the use of inappropriate conversion factors for the two groups (although

520 our value for Prochlorococcus is already fairly high). Taylor et al. (Taylor et al., 2015)

521 employed conversion factors that were lower than our values for their offshore communities, and

522 those values were proportionately larger for Synechococcus relative to Prochlorococcus cell 
523 carbon (101 and $32 \mathrm{fg} \mathrm{C}$ cell $^{-1}$ for Synechococcus and Prochlorococcus, respectively). Use of 524 those values would therefore not explain the apparent discrepancy between our molecular 525 diversity findings (Chow et al., 2013) and the cyanobacterial biomass information presented in 526 this study. Conversion factors employed by Martiny et al. (Martiny et al., 2016) for a coastal 527 study site within the Southern California Bight were more consistent with values employed in 528 our study (120 and $78 \mathrm{fg} \mathrm{C}^{-1 l^{-1}}$ for Synechococcus and Prochlorococcus, respectively).

529 Regardless of the specific conversion factors used for these assemblages, cyanobacterial biomass 530 constituted a minor percentage of total microbial biomass at the SPOT site $(\approx 12-14 \%$; Fig. 5,7 , 531 8). Therefore, the use of other factors would result in only minor differences in the overall 532 contribution of cyanobacteria to total microbial biomass.

533 Nano- and microplankton biomass constituted significant albeit minor fractions of the total 534 microbial biomass at the SPOT site (up to $14 \%$ for nanoplankton, $<10 \%$ for microplankton; Fig. 535 5), but were also the least constrained conversion factors in our study. We attempted to choose a 536 conservative value for estimating the contribution of nanoplankton to total microbial biomass 537 (average cell diameter $=3 \mu \mathrm{m}$, carbon content $=183 \mathrm{fg} \mathrm{C} \mu \mathrm{m}^{3}$, yielding a cell carbon content of $538 \approx 2.6 \mathrm{pg} \mathrm{C}$ cell $\left.^{-1}\right)$. However, data provided on the California Current Ecosystem LTER website 539 (http://oceaninformatics.ucsd.edu/datazoo/data/ccelter/datasets?action=summary\&id=57) for 540 samples collected offshore from our study site indicate that a smaller average carbon content 541 might be more appropriate for nanoplankton in the region. Our estimates of nanoplankton 542 biomass were strongly influenced by our estimated cell size. For example, use of an average cell 543 diameter of $2.5 \mu \mathrm{m}$ rather an 3.0 would reduce our estimate of nanoplankton biomass by nearly $54450 \%$. Conversely, increasing the estimated cell size even modestly (e.g. from an average cell 545 diameter of $3 \mu \mathrm{m}$ to $4 \mu \mathrm{m}$ ) would increase the estimated contribution of nanoplankton to total 546 biomass by nearly 2.4 -fold. Similarly, a number of relationships have been used to convert 547 protists in the microplankton size range to carbon cell ${ }^{-1}$ (see citations in Menden-Deuer and 548 Lessard (2000)), and our conversion factor (138 $\mathrm{pg} \mathrm{C}$ cell $\left.^{-1}\right)$ is generally larger than the median 549 value provided for microplankton on the California Current Ecosystem LTER website. 550 However, microplankton biomass did not comprise a major component of the plankton biomass 551 in our study, so small variances presumably would not impose much change on the overall 552 estimation of microbial biomass among the assemblages. An exception may be the diatoms, that 
553 have been shown to be significantly less carbon dense than other protistan groups (Menden554 Deuer and Lessard, 2000).

555 One means of constraining conversion factors, or assessing their appropriateness, is to 556 compare values generated from cell abundances and group-specific conversion values with 557 independently measured parameters. We performed such an analysis by calculating C:Chl ratios 558 for the samples collected from $5 \mathrm{~m}$ and the SCM. Carbon values were based on the organic 559 carbon contained in all phototrophs (Synechococcus, Prochlorococcus, picoeukarytoic algae, 560 P/MNANO, and microplanktonic phototrophs) and chlorophyll values were obtained 561 fluorometrically from the same samples. Ratios obtained in this manner for samples from the 562 upper water column (averages of 57 and 34 for $5 \mathrm{~m}$ and the SCM, respectively; Fig. 6) were in 563 good agreement with C:Chl values obtained in other studies. Therefore, our estimates of carbon among the microbial phototrophs in our study appear reasonable.

565 Conversion factors for estimating mesozooplankton carbon content from displacement 566 volume are quite variable (Bode et al., 1998). Mesozooplankton biomass in our study was 567 always a very minor component of the total plankton biomass (Fig. 11b) but our collections were 568 all conducted during daytime hours and therefore must be considered underestimates because 569 they did not take into account the contribution of vertically migrating species that swim into 570 surface waters at night. Nonetheless, mesozooplankton comprised such a small component of 571 the overall carbon biomass in the water column that even a doubling of that value would still 572 constitute only a minor fractional change in our estimate of the biomass of the planktonic 573 community.

574 Caveats relating to microbial carbon conversion factors place qualifiers on the contribution of 575 the various plankton assemblages to total microbial biomass as noted above. Similarly, our 576 estimations of total microbial biomass integrated throughout the water column (0-100 $\mathrm{m}$ and 0 $577500 \mathrm{~m}$ ) were influenced by the number of depths for which data were available, and our method 578 of depth integration. The present study encompassed four sampling depths which were chosen to 579 best assess biological assemblages in the upper water column (5 $\mathrm{m}$ and the depth of SCM) and 580 the deeper water column (150 m situated within the permanent oxycline, and $500 \mathrm{~m}$ to represent 581 the deep water community). Plankton biomasses estimated for the two depths above the 582 permanent thermocline and the two below that layer were similar to each other, but the upper 583 water column and lower water column differed considerably (Fig. 7, 8). We integrated microbial 
584 biomass from 0 to $100 \mathrm{~m}$ in this study (Fig. 5a, 9c, 10c) because $100 \mathrm{~m}$ was a reasonable 585 approximation of the bottom of the permanent thermocline (Fig. 1a). Given differences in the microbial biomass between the upper water column and below the thermocline, our choice of the 587 boundary between the SCM and 150 m samples) was the single largest source of variability 588 when estimating integrated biomass. We divided the water column between the depth of the SCM and $150 \mathrm{~m}$ equally in our analysis when determining integrated microbial biomass, which may have exaggerated the importance of the SCM biomass values in the resulting integrations, particularly for the $0-100 \mathrm{~m}$ integration. We estimate that our approach may have yielded values 10-20\% higher than a more conservative integration (data not shown).

\subsection{The biological structure of the plankton community at the SPOT site.}

Studies conducted more than two decades ago established that small microbes (picoplankton; cell size $<2 \mu \mathrm{m}$ ) made up a significant portion of the total living biomass of marine plankton communities (Cho and Azam, 1990; Li et al., 1992; Caron et al., 1995; Roman et al., 1995; Buck et al., 1996; Garrison et al., 2000). Those studies established that bacteria, cyanobacteria and some eukaryotes dominate the biomass of larger protists and zooplankton. Most of that work was carried out in order to characterize the standing stocks of organic carbon in relatively large, oligotrophic oceanic provinces where the contribution of zooplankton might not be expected to

603 be large, and did not include the contribution of viruses, whose significant contributions were not 604 realized at the time.

605 Nonetheless, those studies demonstrated dominance of the living biomass in oceanic 606 plankton by the bacterial assemblage (bacteria + archaea), typically followed by contributions of 607 phototrophic picoeukaryotes, coccoid cyanobacteria and then other plankton assemblages.

608 Bacteria have been shown to dominate the total living microbial biomass of the upper water 609 column even in ice-covered regions of the Arctic (Seuthe et al., 2011). The distribution of 610 microbial biomass at the SPOT site is in general agreement with those previous findings.

611 Bacteria contributed very significantly $(>35 \%)$ to microbial carbon integrated throughout the top $612100 \mathrm{~m}$, with a somewhat larger contribution in the top $500 \mathrm{~m}$ (Fig. 5a,b). An increased 613 contribution of bacterial biomass was anticipated in microbial biomass integrated over $500 \mathrm{~m}$, 614 given that bacterial abundances did not decrease as precipitously with depth as was the case for 
615 many plankton groups (Fig. 7,8). Indeed, it has been estimated that the deep ocean is the 616 repository for approximately $75 \%$ of all prokaryote biomass and a large proportion of all living 617 biomass (Arístegui et al., 2009).

618 One unique aspect of the present study is our estimate of viral carbon as a component of total 619 microbial biomass. Studies of microbial biomass performed until very recently have ignored the 620 contribution of viral carbon to total living microbial carbon in marine plankton communities.

621 This is, in part, due to the fact that viruses are not technically 'alive', but warrant inclusion 622 because they are capable of commandeering the cellular processes of living cells, and their 623 structures contribute to total organic carbon present in the water column. In the present study, 624 viral abundances exceeded all other microbial assemblages enumerated by $>1-6$ orders of 625 magnitude (Table 1), yet viral carbon constituted a rather consistent and modest portion of the 626 total carbon contained in the pelagic community $(\approx 8 \%$ of integrated carbon; Fig. 5a,b, 7,8$)$.

627 This finding is in agreement with present estimates of the global significance of these entities 628 (Suttle, 2005; Suttle, 2007). Suttle (2007) estimated that marine viruses represent approximately $6295 \%$ of the total microbial biomass (prokaryotes, viruses, protists). However, significant 630 uncertainties probably remain with the estimation of viral carbon in the ocean. One recent study 631 reported that viral abundances may be overestimated by $13-28 \%$ using common counting 632 protocols (Mendes et al., 2014), while conversely, another study has suggested that the 633 contribution of RNA viruses (i.e. eukaryote infective agents) has been substantially 634 underestimated in past studies (Steward et al., 2013). Conversion of viral abundances to carbon 635 biomass is also poorly constrained because the size of individual viruses is highly variable (Jover 636 et al., 2014). We employed a conversion factor in this study that is at the upper end of the range 637 in the literature.

638 Phototrophic picoplankton (Synechococcus, Prochlorococcus and phototrophic 639 picoeukaryotes) constituted approximately one quarter of the total depth-integrated microbial 640 carbon in the upper $100 \mathrm{~m}$ at the SPOT site (Fig. 5a). Goericke (2011) reported that the 641 contribution of small phytoplankton (picoplankton and small $(<8 \mu \mathrm{m})$ nanoplankton within the 642 California Current System was a large percentage $(\approx 90 \%)$ of phytoplankton biomass within the 643 CalCOFI grid. Our results are generally in agreement with those findings (Fig. 7, 8) with the 644 exception that diatoms constituted a larger fraction of total phytoplankton biomass, as might be 645 expected for a more-coastal site such as SPOT. Picoplanktonic phytoplankton at the Bermuda 
646

647

648

649

650

651

652

653

654

655

656

657

658

659

660

661

662

663

664

665

666

667

668

669

670

671

672

673

674

675

676

Atlantic Time-series (BATS) station in the Sargasso Sea collectively constituted 1-2 $\mathrm{g} \mathrm{C} \mathrm{m}^{-2}$ in the upper $200 \mathrm{~m}$ of the water column (DuRand et al., 2001). The biomass of picoplankton at the SPOT site was similar to the latter estimate $\left(\approx 1 \mathrm{~g} \mathrm{C} \mathrm{m}^{-2}\right.$ in the upper $100 \mathrm{~m}$; Fig. 5c), even though our coastal site is not as oligotrophic as the BATS site. Phototrophic picoeukaryotes at the SPOT site contributed a somewhat greater fraction of phytoplankton biomass in the euphotic zone than cyanobacteria, especially during spring and summer (Fig. 8).

Nanoplankton biomass (phototrophic/mixotrophic and heterotrophic protists $2-20 \mu \mathrm{m}$ in size) is a poorly constrained parameter in analyses of plankton biomass, as noted above. Total depthintegrated nanoplankton biomass in this study was a modest component (11-14\%) of total microbial biomass (Fig. 5a,b) but slight changes in assumed cell sizes of nanoplankton could easily double that value. Nonetheless, our overall result that nanoplankton contributed a minor fraction of total microbial biomass is in accordance with previous studies that have indicated that nanoplankton biomass is small in comparison to the biomass of picoplankton (Sohrin et al., 2010; Vargas et al., 2012). Heterotrophs exceeded phototrophs in this size category at our study site, perhaps reflecting the near-shore location of the site but also the shallow euphotic zone (Fig. 5a) and therefore limited contribution of phototrophs/mixotrophs to depth-integrated biomass (Table 1; Fig. 5a,b, 7).
The contribution of phagotrophic phytoflagellates (i.e. mixotrophic nanoplankton) to phototrophic nanoplankton in our study is unclear. Published accounts indicate that phagotrophic species can be a significant fraction of the total number of phototrophic nanoplankton in natural plankton communities (Christaki et al., 1999; Unrein et al., 2007; Granda and Anadón, 2008; Moorthi et al., 2009; Vargas et al., 2012), and phagotrophy continues to be demonstrated in an increasing number of phytoplankton species that were formally thought to be exclusively phototrophic (Burkholder et al., 2008; Sanders, 2011; Sanders and Gast, 2011). The contribution of mixotrophs to total microbial biomass at the SPOT site must still have been low, however, because the total contribution of phototrophic nanoplankton (phototrophs + mixotrophs) was typically $<5 \%$ of total biomass.

Microplanktonic phytoplankton and zooplankton $(20-200 \mu \mathrm{m})$ comprised approximately 15\% of the total depth-integrated microbial biomass (Fig. 5a) and not more than $\approx 10 \mu \mathrm{g} \mathrm{C}^{-1}$ in surface samples at the SPOT sampling site (Fig. 7, 8). Phytoplankton $>20 \mu \mathrm{m}$ at the site were almost exclusively diatoms and dinoflagellates, with diatoms typically the dominant contributor. 
677 Microphytoplankton can occasionally constitute major, but typically highly variable, components 678 of the total phytoplankton biomass in the Southern California Bight due to episodic blooms (Kim et al., 2009; Nezlin et al., 2012; Seubert et al., 2013). The modest contribution of

680 microphytoplankton at our study site indicates the typically oligotrophic nature of this coastal 681 ecosystem just $15 \mathrm{~km}$ from the mainland, and is also consistent with the low chlorophyll values observed throughout the year at the SPOT site (Fig. 4). A review of data on diatom biomass globally yielded a median value of $\approx 11 \mu \mathrm{g} \mathrm{C}^{-1}$ (Leblanc et al., 2012), a number that is in close 684 agreement with our estimate of diatom biomass at the SPOT site obtained in this study (Fig. 7, 685 8). Heterotrophic microplankton (ciliate) biomass in our study was always low and never constituted more than a few percent of total microbial biomass (Fig. 5a,b, 7-10).

Our results regarding microbial biomass are very much in agreement with the results of Taylor et al. (2015), who estimated autotrophic biomass within the CalCOFI study region, including stations within the Channel Islands in the region of the SPOT station. Their southern coastal station closest to the SPOT site yielded estimates of autotrophic carbon that were very consistent with the summed phototroph biomass in the present study (Synechococcus + Prochlorococcus + photosynthetic picoeukaryotes, nanoplankton and microplankton (note the 5 $693 \mathrm{~m}$ and SCM values in Fig. 7, 8). Such agreement between studies would imply that our choices 694 for conversion factors in the present study were reasonable.

695 The contribution of mesozooplankton biomass ( $>200 \mu \mathrm{m}$ ) averaged $<5 \%$ of total plankton 696 biomass throughout the year, with slightly larger contributions during late spring and summer 697 (Fig. 11). Only a few of our highest values $\left(\approx 5 \mu \mathrm{g} \mathrm{C}{ }^{-1}\right)$ were within the range of mesozooplankton biomass values reported for the southern California section of the California 699 Current System, when converted to similar units (Lavaniegos and Ohman, 2007; Décima et al., 700 2011). Our generally lower values may reflect avoidance of the smaller net used in our study, or 701 inadequate sampling of vertically migrating species (all our tows were conducted during the 702 day). Our estimates of the overall contribution of mesozooplankton biomass relative to that of 703 microbial assemblages, however, fall within the range of more expansive datasets. A global 704 inventory of mesozooplankton biomass in the ocean estimated a value of $0.24 \mathrm{Pg} \mathrm{C}$ (Buitenhuis 705 et al., 2010) in that plankton compartment, while bacterial biomass was estimated to be 706 approximately $5 \mathrm{X}$ greater at $1.2 \mathrm{Pg} \mathrm{C}$ (Buitenhuis et al., 2012). A global analysis of 
707 mesozooplankton and macrozooplanton biomass yielded mean values that were comparable

708 (Moriarty et al., 2013; Moriarty and O'Brien, 2013).

709 Seasonal and monthly estimates of depth-specific and depth-integrated biomass values (Fig.

710 8-10) for the various plankton groups revealed modest levels of variability on those times scales.

711 Depth-specific biomass estimates during spring and summer were $\approx 40 \%$ greater than values

712 during fall and winter (Fig. 8). Month-to-month variability in depth-integrated biomass (Fig.

713 9c,d) was somewhat greater than seasonal variability (Fig. 10c,d), except for a few months when

714 microbial biomass was approximately double most other months. Relatively low seasonal

715 variability reflects the subtropical nature of the SPOT site with its small annual amplitudes of

716 temperature and other chemical/physical parameters (Fig. 2). The monthly and seasonal

717 variability in standing stocks of microbial biomass is consistent with previously reported values

718 of monthly-to-interannual variability observed at the sampling site, and even small-scale

719 temporal and spatial variability (Chow et al., 2013; Kim et al., 2013; Lie et al., 2013).

720 The concentrations of total heterotrophic microbial biomass and total phototrophic microbial

721 biomass were relatively equitable at the SPOT site (Fig. 5a,b, 7). The significant proportion of

722 heterotrophs was largely a consequence of the large contribution of bacterial biomass. Roman et

723 al. (1995) noted that carbon among the heterotrophic assemblages in surface waters of the

724 Sargasso Sea was greater than carbon contained in phototrophs during the summer, but was more

725 equitable in spring. The authors noted that the partitioning of living biomass in the upper $100 \mathrm{~m}$

726 was not a broad-based pyramid with photosynthetic biomass exceeding heterotrophic biomass.

727 The situation appears to be similar at our coastal site. Our results indicate that heterotrophic

728 microbial carbon at our study site constituted approximately $2 \mathrm{~g} \mathrm{C} \mathrm{m}^{-2}$ integrated throughout the

729 top $100 \mathrm{~m}$ (Fig. 5c). Sohrin et al. (2010) reviewed depth-integrated carbon biomass values for

730 heterotrophic prokaryotes, heterotrophic nanoflagellates and ciliates from various epipelagic

731 oceanic ecosystems (see their Table 6). Values generally ranged from a few $10 \mathrm{~s} \mathrm{mg} \mathrm{C} \mathrm{m}^{-2}$ to $>2$

$732 \mathrm{~g} \mathrm{C} \mathrm{m}^{-2}$ in the upper $100 \mathrm{~m}$, values in agreement with our findings.

\subsection{Contribution of microbial biomass to POC and flux}

To our knowledge, our study is the most complete assessment of the microbial assemblages 
planktonic communities (e.g. phytoplankton, bacteria or viruses) but complete assessments are rare because of the various expertise and methodologies required to characterize all microbial groups. In particular, most studies that have counted viruses have not placed these entities into a community framework. Our study therefore enables an assessment of the relative contributions of specific plankton groups to total microbial organic carbon and total microbial biomass to POC at our study site in the eastern North Pacific.

744 Our estimates of microbial biomass in the upper water column $\left(\approx 60 \mu \mathrm{g} \mathrm{C}^{-1}\right.$; Fig. 7) and 745 depth-integrated microbial carbon within the upper $100 \mathrm{~m}\left(\approx 4 \mathrm{~g} \mathrm{C} \mathrm{m}^{-2}\right.$; Fig. 5c) fall within the 746 range of values estimated in other oceanic provinces (Ishizaka et al., 1997; Garrison et al., 2000), 747 regionally in the Southern California Current Ecosystem (Taylor et al., 2015), and one previous 748 study in the San Pedro Basin (Nelson et al., 1987). Global databases of POC in surface waters occur over a wide range in the world ocean from $<10$ to $>1000 \mu \mathrm{g} \mathrm{C}^{-1}(<1$ to $>100 \mu \mathrm{M} \mathrm{C})$ across ecosystems spanning oligotrophic oceanic gyres to highly productive coastal environments (Gardner et al., 2006; Stramski et al., 2008). The amount of living microbial 752 biomass is generally considered to be a significant component of the total POC, even in highly 753 oligotrophic ecosystems (Roman et al., 1995; Kawasaki et al., 2011). POC was not routinely 754 measured as a part of the San Pedro Ocean Time-series during our study, but typical standing 755 stocks of POC in the Santa Barbara basin to the north of the San Pedro Basin have been reported 756 to range between $\approx 500$ and 3,700 $\mu \mathrm{g} \mathrm{C}^{-1}$ (Shipe et al., 2002). This range of values implies that 757 microbial carbon at the SPOT site constitutes only a few to $>10 \%$ of total POC in surface waters, 758 although the waters of the Santa Barbara basin are more productive than the San Pedro Basin and 759 thus may be a poor indicator of total POC at the SPOT site. Martiny (2016) noted that microbial 760 carbon constituted $>40 \%$ (median) of the POC in samples collected at a pier located at Newport 761 Beach, CA, approximately $30 \mathrm{~km}$ to the east of our sampling site. Studies in the Sargasso Sea 762 and Arabian Sea have reported that the carbon content of the microbial community in those 763 regions comprised approximately $25-50 \%$ of total POC (Caron et al., 1995; Garrison et al., 764 2000). Our low values may indicate that the conversion factors employed in the present study 765 were overly conservative for estimating microbial biomass.

766 Standing stocks of microbial assemblages in surface waters of the San Pedro Basin place 767 constraints on their potential contribution to water column processes as well as their contribution 768 to the sinking of POC into deep water in the basin. Simple mass balance calculations provide 
confirmation that the values we obtained in the present study are realistic in relation to flux measurements. For example, the vertical flux of organic carbon out of the euphotic zone in the

771 Santa Monica and San Pedro Basins has been estimated to range seasonally from $\approx 20$ to $>150$

$772 \mathrm{mg} \mathrm{C} \mathrm{m}{ }^{-2} \mathrm{~d}^{-1}$ (Nelson et al., 1987; Thunell et al., 1994; Berelson and Stott, 2003; Collins et al., 773 2011; Haskell II, 2015; Haskell II et al., 2016). Estimated phytoplankton biomass in surface

774 waters at the SPOT site in the present study averaged $22 \mu \mathrm{g} \mathrm{Cl}^{-1}$ in samples within the euphotic 775 zone (Fig. 7). This value corresponds to an integrated phytoplankton biomass of $880 \mathrm{mg} \mathrm{C} \mathrm{m}^{-2}$, 776 assuming a $40 \mathrm{~m}$ euphotic zone (Fig. 3). Given that value for the phytoplankton standing stock, 777 and assuming a rate of primary production equivalent to a doubling time of two days for the phytoplankton assemblage, a vertical flux of $\approx 10 \%$ of primary production could support a vertical flux of $44 \mathrm{mg} \mathrm{C} \mathrm{m}^{-2} \mathrm{~d}^{-1}$. There is, therefore, good agreement between values obtained from these disparate studies and measurements.

An interesting observation in our study was the high relative abundances of diatoms in samples collected at 150 and $500 \mathrm{~m}$ (Fig. 7, 8). This unexpected result may in part be a consequence of including non-living diatoms with frustules containing cellular debris as living cells. However, it has been noted that the vertical flux of matter into sediment traps at $550 \mathrm{~m}$ and $800 \mathrm{~m}$ in the San Pedro Basin were strongly and closely correlated (Collins et al., 2011), while other studies in the region have implicated rapid transport of material into deeper waters during periods of high flux (Sekula-Wood et al., 2009; Bishop et al., 2016). Nelson et al. (1987) noted that intact phytoplankton were a minor but measurable component of sediment trap material, and generally larger contributions were episodic and coincided with phytoplankton blooms in the region. Our observation that diatoms contributed significantly to total microbial

791 biomass in deeper samples in San Pedro Basin (Fig. 7) may imply a significant and relatively 792 constant contribution of diatoms to sinking particles at the SPOT site.

\subsection{Concluding remarks}

A predictive understanding of biogeochemical processes in coastal pelagic ecosystems, and

797 how they might respond to environmental change (either natural or anthropogenic), is predicated 798 on knowledge of the microbial taxa that dominate those ecosystems. This study provides the most complete assessment to date of the organic carbon associated with the various microbial 
assemblages of a coastal planktonic community, as well as the vertical, monthly and seasonal

801 variability associated with these assemblages, at the site of a long-term microbial oceanographic

802 time series. Studies during the past few decades have provided great insight into the species

803 diversity and activities of microbial communities, made possible largely through the application

804 of cutting-edge genetic approaches (DeLong and Karl, 2005; Caron, 2009). Characterizing the

805 biomass associated with this vast array of microbes has garnered less attention in recent years but

806 is also essential for helping constrain the potential activities of these assemblages in natural

807 aquatic communities. Coupled to diversity and rate measurements conducted, the analysis

808 contained in this study enables in-depth analysis and modeling of microbial processes and carbon

809 and energy flow in the coastal ecosystem off Southern California (Landry et al., 2009; Connell et

810 al., In review).

\section{Acknowledgements}

813 This work was supported by National Science Foundation grants MCB-0703159, MCB-0084231

814 and OCE-1136818. The authors thank the Captain and Crew of the R/V Yellowfin, Troy

815 Gunderson for CTD operations and processing of environmental samples, the Wrigley Institute

816 for Environmental Studies for fieldwork support, and an anonymous reviewer who offered

817 comments that were helpful for improving the discussion of microbial biomass estimation.

\section{References}

820 Aksnes, D.L., Ohman, M.D. 2009. Multi-decadal shoaling of the euphotic zone in the southern sector of the California Current System. Ecol. Res. 54, 1272-1281

822 Alber, M., Reed, D., McGlathery, K. 2013. Coastal long term ecological research: introduction to 823 the special issue. Oceanography 26, 14-17

824 Anderson, T.R., Ducklow, H.W. 2001. Microbial loop carbon cycling in ocean environments

825 studied using a simple steady-state model. Aq. Microb. Ecol. 26, 37-49

826 Arístegui, J., Gasol, J.M., Duarte, C.M., Herndl, G.J. 2009. Microbial oceanography of the dark ocean's pelagic realm. Limnol. Oceanogr. 54, 1501-1529

828 Beman, J.M., Steele, J., Fuhrman, J.A. 2011. Co-occurrence patterns for abundant marine 829 archaeal and bacterial lingeages in the deep chlorophyll maximum of coastal California. ISME J. 
Berelson, W.M. 1991. The flushing of two deep-sea basins, southern California borderland Limnol. Oceanogr. 36, 1150-1166

Berelson, W.M., Stott, L.D. 2003. Productivity and organic carbon rain to the California margin seafloor: Modern and paleoceanographic perspectives. Paleoceanography 18, 1002

Bishop, J.K.B., Fong, M.B., Wood, T.J. 2016. Robotic observations of high wintertime carbon export in California coastal waters. Biogeosci. Disc. 2016, 1-32

Bode, A., Álvarez-Ossorio, M.T., González, N. 1998. Estimations of mesozooplankton biomass in a coastal upwelling area off NW Spain. J. Plankton Res. 20, 1005-1014

Brown, S.L., Landry, M.R., Neveux, J., Dupouy, C. 2003. Microbial community abundance and biomass along a 180 degrees transect in the equatorial Pacific during an El NinoSouthern Oscillation cold phase. J. Geophys. Res. (Oceans) 108

Buck, K.R., Chavez, F.P., Campbell, L. 1996. Basin-wide distributions of living carbon components and the inverted trophic pyramid of the central gyre of the North Atlantic Ocean, summer 1993. Aq. Microb. Ecol. 10, 283-298

Buitenhuis, E.T., Li, W.K.W., Lomas, M.W., Karl, D.M., Landry, M.R., Jacquet, S. 2012. Bacterial biomass distribution in the global ocean. Earth Systems Science Data Discussions 5, 301-315

Buitenhuis, E.T., Rivkin, R.B., Sailley, S., Le Quéré, C. 2010. Biogeochemical fluxes through microzooplankton. Global Biogeochem. Cycles 24, GB4015

Burkholder, J.M., Glibert, P.M., Skelton, H.M. 2008. Mixotrophy, a major mode of nutrition for harmful algal species in eutrophic waters. Harmful Algae 8, 77-93

Calbet, A., Landry, M.R. 2004. Phytoplankton growth, microzooplankton grazing, and carbon cycling in marine systems. Limnol. Oceanogr. 49, 51-57

Calbet, A., Saiz, E. 2005. The ciliate-copepod link in marine food ecosystems. Aq. Microb. Ecol. $38,157-167$

Caron, D.A. 2009. New accomplishments and approaches for assessing protistan diversity and ecology in natural ecosystems. BioScience 59, 287-299

Caron, D.A., Countway, P.D., Jones, A.C., Kim, D.Y., Schnetzer, A. 2012. Marine protistan diversity. Ann. Rev. Mar. Sci. 4, 467-493

Caron, D.A., Dam, H.G., Kremer, P., Lessard, E.J., Madin, L.P., Malone, T.C., Napp, J.M., Peele, E.R., Roman, M.R., Youngbluth, M.J. 1995. The contribution of microorganisms 
to particulate carbon and nitrogen in surface waters of the Sargasso Sea near Bermuda. Deep-Sea Res. 42, 943-972

864 Casey, J.R., Aucan, J.P., Goldberg, S.R., Lomas, M.W. 2013. Changes in partitioning of carbon amongst photosynthetic pico- and nano-plankton groups in the Sargasso Sea in response to changes in the North Atlantic Oscillation. Deep-Sea Res. II 93, 58-70

Cheung, W.W.L., Watson, R., Pauly, D. 2013. Signature of ocean warming in global fisheries catch. Nature 497, 365-368

Cho, B.C., Azam, F. 1990. Biogeochemical significance of bacterial biomass in the ocean's euphotic zone. Mar. Ecol. Prog. Ser. 63, 253-259

Chow, C.-E.T., Fuhrman, J.A. 2012. Seasonality and monthly dynamics of marine myovirus communities. Environ. Microbiol. 14, 2171-2183

Chow, C.-E.T., Kim, D.Y., Sachdeva, R., Caron, D.A., Fuhrman, J.A. 2014. Top-down controls on bacterial community structure: microbial network analysis of bacteria, T4-like viruses and protists. ISME J. 8, 816-829

Chow, C.-E.T., Sachdeva, R., Cram, J.A., Steele, J.A., Needham, D.M., Patel, A., Parada, A.E., Fuhrman, J.A. 2013. Temporal variability and coherence of euphotic zone bacterial communities over a decade in the Southern California Bight. ISME J. 7, 2259-2273

Church, M.J., Wai, B., Karl, D.M., DeLong, E.F. 2010. Abundances of crenarchaeal amoA genes and transcripts in the Pacific Ocean. Environ. Microbiol. 12, 679-688

Collins, L.E., Berelson, W., Hammond, D.E., Knapp, A., Schwartz, R., Capone, D. 2011. Particle fluxes in San Pedro Basin, California: A four-year record of sedimentation and

Countway, P.D., Vigil, P.D., Schnetzer, A., Moorthi, S.D., Caron, D.A. 2010. Seasonal analysis of protistan community structure and diversity at the USC Microbial Observatory (San Pedro Channel, North Pacific Ocean). Limnol. Oceanogr. 55, 2381-2396 
Cram, J.A., Chow, C.-E.T., Sachdeva, R., Needham, D.M., Parada, A.E., Steele, J.A., Fuhrman, J.A. 2014. Seasonal and interannual variability of the marine bacterioplankton community throughout the water column over ten years. ISME J.

Décima, M., Landry, M.R., Rykaczewski, R.R. 2011. Broad scale patterns in mesozooplankton biomass and grazing in the eastern equatorial Pacific. Deep-Sea Res. II 58, 387-399 del Giorgio, P.A., Bird, D.F., Prairie, Y.T., Planas, D. 1996. Flow cytometric determination of bacterial abundance in lake plankton with the green nucleic acid stain SYTO 13. Appl. Environ. Microbiol. 41, 783-789

DeLong, E.F., Karl, D.M. 2005. Genomic perspectives in microbial oceanography. Nature 437, 336-342

Dennett, M.R., Mathot, S., Caron, D.A., Smith, W.O., Lonsdale, D.J. 2001. Abundance and distribution of phototrophic and heterotrophic nano- and microplankton in the southern Ross Sea. Deep-Sea Res. II 48, 4019-4037

Duarte, C.M., Regaudie-de-Gioux, A., Arrieta, J.M., Delgado-Huertas, A., Agustí, S. 2013. The Oligotrophic Ocean Is Heterotrophic*. Ann. Rev. Mar. Sci. 5, 551-569

Ducklow, H.W., Doney, S.C. 2013. What is the metabolic state of the oligotrophic ocean? A Debate. Ann. Rev. Mar. Sci. 5, 525-533

DuRand, M.D., Olson, R.J., Chisholm, S.W. 2001. Phytoplankton population dynamics at the Bermuda Atlantic Time-series station in the Sargasso Sea. Deep-Sea Res. II 48, 19832003

Fuhrman, J.A. 2009. Microbial community structure and its functional implications. Nature 459, 193-199

Fuhrman, J.A., Steele, J., Sun, F., Xia, L., Countway, P.D., Caron, D.A. American Society of Limnology and Oceangraphy, Nice, France, 2009.

Fukuda, R., Ogawa, H., Nagata, T., Koike, I. 1998. Direct determination of carbon and nitrogen contents of natural bacterial assemblages in marine environments. Appl. Environ. Microbiol. 64, 3352-3358

Gardner, W.D., Mishonov, A.V., Richardson, M.J. 2006. Global POC concentrations from insitu and satellite data. Deep-Sea Res. II 53, 718-740

Garrison, D.L., Gowing, M.M., Hughes, M.P., Campbell, L., Caron, D.A., Dennett, M.R., Shalapyonok, A., Olson, R.J., Landry, M.R., Brown, S.L., Liu, H.B., Azam, F., Steward, 
G.F., Ducklow, H.W., Smith, D.C. 2000. Microbial food web structure in the Arabian Sea: a US JGOFS study. Deep-Sea Res. II 47, 1387-1422

Goericke, R. 2011. The size structure of marine phytoplankton - what are the rules? CalCOFI Report 52, 198-204

Gordon, L.I., Jennings, J.J.C., Ross, A.A., Krest, J.M. 1993. A suggested protocol for continuous flow automated analysis of seawater nutrients (phosphate, nitrate, nitrite and silicic acid) in the WOCE Hydrographic

Program and the Joint Global Ocean Fluxes Study, WHP Operations And Methods, College of Oceanic and Atmospheric Sciences Oregon State University: Corvallis, Oregon

Granda, A.P., Anadón, R. 2008. The annual cycle of nanoflagellates in the central Cantabrian Sea (Bay of Biscay). J. Mar. Systems 72, 298-308

Grasshoff, K., Kremling, K., Ehrhardt, M. 2007. Methods of Seawater Anlaysis. Weinheim, Germany: Wiley-VCH GmbH.

Hales, B., Takahashi, T., Bandstra, L. 2005. Atmospheric $\mathrm{CO}_{2}$ uptake by a coastal upwelling system. Global Biogeochem. Cycles 19, GB1009

Hamersley, M.R., Turk, K.A., Leinweber, A., Gruber, N., Zehr, J.P., Gunderson, T., Capone, D.G. 2011. Nitrogen fixation within the water column associated with two hypoxic basins in the Southern California Bight. Aq. Microb. Ecol. 63, 193-205

Harris, R.P., Wiebe, P.H., Lenz, J., Skjoldal, H.R., Huntley, M. 2000. Zooplankton methodology manual.pp. 684. London: Academic Press.

Haskell II, W.Z. 2015. Ecosystem export efficiency in an upwelling region: a two-year time series study of vertical transport, particle export and in-situ net and gorss oxygen production. Ph.D. thesis. University of Southern California, Los Angeles. 305 pp.

Haskell II, W.Z., Prokopenko, M.G., Hammond, D.E., Stanley, R.H.R., Berelson, W., Baronas,

951 Hofmann, G.E., Blanchette, C.A., Rivest, E.B., Kapsenberg, L. 2013. Taking the pulse of marine 952 ecosystems: The importance of coupling long-term physical and biological observations 953 in the context of global change biology. Oceanography 26, 140-148 
954 Hood, R.R., Laws, E.A., Armstrong, R.A., Bates, N.R., Brown, C.W., Carlson, C.A., Chai, F., 955 Doney, S.C., Falkowski, P.G., Feely, R.A., Friedrichs, M.A.M., Landry, M.R., Keith

Howard, M.D.A., Sutula, M., Caron, D.A., Chao, Y., Farrara, J.D., Frenzel, H., Jones, B., Moore, J., Nelson, D.M., Richardson, T.L., Salihoglu, B., Schartau, M., Toole, D.A., Wiggert, J.D. 2006. Pelagic functional group modeling: Progress, challenges and prospects. Deep-Sea Res. II 53, 459-512 Robertson, G., McLaughlin, K., Sengupta, A. 2014. Anthropogenic nutrient sources rival natural sources on small scales in the coastal waters of the Southern California Bight. Limnol. Oceanogr. 59, 285-297

Ishizaka, J., Harada, K., Ishikawa, K., Kiyosawa, H., Furusawa, H., Watanabe, Y., Ishida, H., Suzuki, K., Handa, N., Takahashi, M. 1997. Size and taxonomic plankton community structure and carbon flow at the equator, $175^{\circ}$ E during 1990-1994. Deep-Sea Res. II 44, 1927-1949

Jover, L.F., Effler, T.C., Buchan, A., Wilhelm, S.W., Weitz, J.S. 2014. The elemental composition of virus particles: implications for marine biogeochemical cycles. Nature Rev. Microbiol. 12, 519-528

Kahru, M., Kudela, R., Manzano-Sarabia, M., Mitchell, B.G. 2009. Trends in primary production in the California Current detected with satellite data. J. Geophys. Res.: Oceans 114, $\mathrm{C} 02004$

Karl, D.M., Church, M.J. 2014. Microbial oceanography and the Hawaii Ocean Time-series programme. Nat Rev Micro 12, 699-713

Karl, D.M., Michaels, A.F. 1996. The Hawaiian Ocean Time-series (HOT) and Bermuda Atlantic Time-series study (BATS). Deep-Sea Res. II 43, 127-128

Kawasaki, N., Sohrin, R., Ogawa, H., Nagata, T., Benner, R. 2011. Bacterial carbon content and the living and detrital bacterial contributions to suspended particulate organic carbon in the North Pacific Ocean. Aq. Microb. Ecol. 62, 165-176

Kepner, R.L., Wharton, R.A., Suttle, C.A. 1998. Viruses in Antarctic lakes. Limnol. Oceanogr. 43, 1754-1761

Kim, D.Y., Countway, P.D., Jones, A.C., Schnetzer, A., Yamashita, W., Tung, C., Caron, D.A. 2013. Monthly to interannual variability of microbial eukaryote assemblages at four depths in the eastern North Pacific. ISME J. 
Kim, H.-J., Miller, A.J., McGowan, J., Carter, M.L. 2009. Coastal phytoplankton blooms in the Southern California Bight. Prog. Oceanogr. 82, 137-147

Kudela, R.M., Pitcher, G., Probyn, T., Figueiras, F., Moita, T., Trainer, V.L. 2005. Harmful algae blooms in coastal upwelling systems. Oceanography 18, 184-197

Landry, M.R., Ohman, M.D., Goericke, R., Stukel, M.R., Tsyrklevich, K. 2009. Lagrangian studies of phytoplankton growth and grazing relationships in a coastal upwelling ecosystem off Southern California. Prog. Oceanogr. 83, 208-216

Leblanc, K., Arístegui, J., Armand, L., Assmy, P., Beker, B., Bode, A., Breton, E., Cornet, V., Gibson, J., Gosselin, M.-P., Kopczynska, E., Marshall, H., Peloquin, J., Piontkovski, S., Poulton, A.J., Quéguiner, B., Schiebel, R., Shipe, R., Stefels, J., van Leeuwe, M.A., Varela, M., Widdicombe, C., Yallop, M. 2012. A global diatom database - abundance, biovolume and biomass in the world ocean. Earth System Sci. Data 4, 149-165

Lee, S., Fuhrman, J.A. 1987. Relationships between biovolume and biomass of naturally derived marine bacterioplankton. Appl. Environ. Microbiol. 53, 1298-1303

Levitus, S. 1982. Climatological atlas of the world ocean, Rockville, MD

Li, W.K.W., Dickie, P.M., Irwin, B.D., Wood, A.M. 1992. Biomass of bacteria, cyanobacteria, prochlorophytes and photosynthetic eukaryotes in the Sargasso Sea. Deep-Sea Res. 39, 501-519

Lie, A.A.Y., Kim, D.Y., Schnetzer, A., Caron, D.A. 2013. Small-scale temporal and spatial variations in protistan community composition at the San Pedro Ocean Time-series station off the coast of southern California. Aq. Microb. Ecol. 70, 93-110

Martiny, A.C., Talarmin, A., Mouginot, C., Lee, J.A., Huang, J.S., Gellene, A.G., Caron, D.A. 2016. Biogeochemical interactions control a temporal succession in the elemental composition of marine communities. Limnol. Oceanogr. 61, 531-542

McMahon, K.W., McCarthy, M.D., Sherwood, O.A., Larsen, T., Guilderson, T.P. 2015. Millennial-scale plankton regime shifts in the subtropical North Pacific Ocean. Science $350,1530-1533$

Menden-Deuer, S., Lessard, E.J. 2000. Carbon to volume relationships for dinoflagellates, diatoms, and other protist plankton. Limnol. Oceanogr. 45, 569-579 
Mendes, C., Santos, L.s., Cunha, Ç., Gomez, N.M., Almeida, A. 2014. Proportion of prokaryotes enumerated as viruses by epifluorescence microscopy. Annals Microbiol. 64, 773-778

Moorthi, S.D., Caron, D.A., Gast, R.J., Sanders, R.W. 2009. Mixotrophy: a widespread and important ecological strategy for planktonic and sea-ice nanoflagellates in the Ross Sea, Antarctica. Aq. Microb. Ecol. 54, 269-277

Moriarty, R., Buitenhuis, E.T., Le Quére, C., Gosselin, M.-P. 2013. Distribution of known macrozooplankton abundance and biomass in the global ocean. Earth System Sci. Data 5, $241-257$

Moriarty, R., O'Brien, T.D. 2013. Distribution of mesozooplankton biomass in the global ocean. Earth System Sci. Data 5, 45-55

Nelson, J.R., Beers, J.R., Eppley, R.W., Jackson, G.A., McCarthy, J.J., Soutar, A. 1987. A particle flux study in the Santa Monica-San Pedro Basin off Los Angeles: particle flux, primary production, and transmissometer survey. Cont. Shelf Res. 7, 307-328

Nezlin, N.P., Sutula, M.A., Stumpf, R.P., Sengupta, A. 2012. Phytoplankton blooms detected by SeaWiFS along the central and southern California coast. J. Geophys. Res.-Oceans 117, $10.1029 / 2011 \mathrm{jc} 007773$

Noble, R.T., Fuhrman, J.A. 1998. Use of SYBR Green I for rapid epifluorescence counts of marine viruses and bacteria. Aq. Microb. Ecol. 14, 113-118

Parsons, T.R., Maita, Y., Lalli, C.M. 1984. A manual of chemical and biological methods for seawater analysis. Oxford: Pergamon Press. 173 pp.

Roman, M.R., Caron, D.A., Kremer, P., Lessard, E.J., Madin, L.P., Malone, T.C., Napp, J.M., Peele, E.R., Youngbluth, M.J. 1995. Spatial and temporal changes in the partitioning of organic carbon in the plankton community of the Sargasso Sea off Bermuda. Deep-Sea Res. I 42, 973-992

Rykaczewski, R.R., Dunne, J.P. 2010. Enhanced nutrient supply to the California Current Ecosystem with global warming and increased stratification in an earth system model. Geophys. Res. Lett. 37, L21606

Samuelsson, K., Berglund, J., Haecky, P., Andersson, A. 2002. Structural changes in an aquatic microbial food web caused by inorganic nutrient addition. Aq. Microb. Ecol. 29, 29-38 
1045

1046

1047

1048

1049

1050

1051

1052

1053

1054

1055

1056

1057

1058

1059

1060

1061

1062

1063

1064

1065

1066

1067

1068

1069

1070

1071

1072

1073

1074

Sanders, R.W. 2011. Alternative nutritional strategies in protists: symposium introduction and a review of freshwater protists that combine photosynthesis and heterotrophyl. J. Eukary. Microbiol. 58, 181-184

Sanders, R.W., Gast, R.J. 2011. Bacterivory by phototrophic picoplankton and nanoplankton in Arctic waters. FEMS Microbiol. Ecol. 82, 242-253

Sanders, R.W., Porter, K.G. 1988. Phagotrophic phytoflagellates. Adv. Microb. Ecol. 10, 167192

Schnetzer, A., Miller, P.E., Schnaffner, R.A., Stauffer, B.A., Jones, B.H., Weisberg, S.B., DiGiacomo, P.M., Berelson, W.M., Caron, D.A. 2007. Blooms of Pseudo-nitzschia and domoic acid in the San Pedro Channel and Los Angeles harbor areas of the Southern California Bight, 2003-2004. Harmful Algae 6, 372-387

Schnetzer, A., Moorthi, S.D., Countway, P.D., Gast, R.J., Gilg, I.C., Caron, D.A. 2011. Depth matters: microbial eukaryote diversity and community structure in the eastern North Pacific revealed through environmental gene libraries. Deep-Sea Res. I 58, 16-26

Sekula-Wood, E., Schnetzer, A., Benitez-Nelson, C.R., Anderson, C., Berelson, W., Brzezinksi, M., Burns, J., Caron, D.A., Cetinic, I., Ferry, J., Fitzpatrick, E., Jones, B., Miller, P.E., Morton, S.L., Schaffner, R., Siegel, D., Thunell, R. 2009. Rapid downward transport of the neurotoxin domoic acid in coastal waters. Nature Geosci. 2, 272-275

Seubert, E.L., Gellene, A.G., Howard, M.D.A., Connell, P., Ragan, M., Jones, B.H., Runyan, J., Caron, D.A. 2013. Seasonal and annual dynamics of harmful algae and algal toxins revealed through weekly monitoring at two coastal ocean sites off southern California, USA. Environ. Sci. Pollution Res. 20, 6878-6895

Seuthe, L., Töpper, B., Reigstad, M., Thyrhaug, R., Vaquer-Sunyer, R. 2011. Microbial communities and processes in ice-covered Arctic waters of the northwestern Fram Strait $\left(75\right.$ to $\left.80^{\circ} \mathrm{N}\right)$ during the vernal pre-bloom phase. Aq. Microb. Ecol. 64, 253-266

Sherr, B.F., Sherr, E.B., Caron, D.A., Vaulot, D., Worden, A.Z. 2007. A sea of microbes: oceanic protists. Oceanography 20, 102-106

Sherr, E.B., Caron, D.A., Sherr, B.F. 1993. Staining of heterotrophic protists for visualization via epifluorescence microscopy In Handbook of methods in aquatic microbial ecology, ed. Kemp, P., Sherr, B., Sherr, E., Cole, J., pp. 213-227. Boca Raton: Lewis Publishers 
1075

1076

1077

1078

1079

1080

1081

1082

1083

1084

1085

1086

1087

1088

1089

1090

1091

1092

1093

1094

1095

1096

1097

1098

1099

1100

1101

1102

1103

1104

Sherr, E.B., Sherr, B.F. 2007. Heterotrophic dinoflagellates: a signficant component of microzooplankton biomass and major grazers of diatoms in the sea. Mar. Ecol. Prog. Ser. 352, 187-197

Shipe, R.F., Passow, U., Brzezinski, M.A., Graham, W.M., Pak, D.K., Siegel, D.A., Alldredge, A.L. 2002. Effects of the 1997-98 El Niño on seasonal variations in suspended and sinking particles in the Santa Barbara basin. Prog. Oceanogr. 54, 105-127

Sohrin, R., Imazawa, M., Fukuda, H., Suzuki, Y. 2010. Full-depth profiles of prokaryotes, heterotrophic nanoflagellates, and ciliates along a transect from the equatorial to the subarctic central Pacific Ocean. Deep-Sea Res. II 57, 1537-1550

Steele, J.A., Countway, P.D., Xia, L., Vigil, P.D., Beman, J.M., Kim, D.Y., Chow, C.-E.T., Sachdeva, R., Jones, A.C., Schwalbach, M.S., Rose, J.M., Hewson, I., Patel, A., Sun, F., Caron, D.A., Fuhrman, J.A. 2011. Marine bacterial, archaeal and protistan association networks reveal ecological linkages. ISME J. 5, 1414-1425

Steinberg, D.K., Carlson, C.A., Bates, N.R., Johnson, R.J., Michaels, A.F., Knap, A.H. 2001. Overview of the US JGOFS Bermuda Atlantic Time-series Study (BATS): a decade-scale look at ocean biology and biogeochemistry. Deep-Sea Res. II 48, 1405-1447

Steward, G.F., Culley, A.I., Mueller, J.A., Wood-Charlson, E.M., Belcaid, M., Poisson, G. 2013. Are we missing half of the viruses in the ocean[quest]. ISME J. 7, 672-679

Stoecker, R.K., Gustafson, D.E., Verity, P.G. 1996. Micro- and mesoprotozooplankton at $140^{\circ} \mathrm{W}$ in the equatorial Pacific: heterotrophs and mixotrophs. Aq. Microb. Ecol. 10, 273-282

Stramski, D., Reynolds, R.A., Babin, M., Kaczmarek, S., Lewis, M.R., Röttgers, R., Sciandra, A., Stramska, M., Twardowski, M.S., Franz, B.A., Claustre, H. 2008. Relationships between the surface concentration of particulate organic carbon and optical properties in the eastern South Pacific and eastern Atlantic Oceans. Biogeosciences 5, 171-201

Suttle, C.A. 2005. Viruses in the sea. Nature 437, 356-361

Suttle, C.A. 2007. Marine viruses - major players in the global ecosystem. Nat. Rev. Microbiol. $5,801-812$

Sydeman, W.J., García-Reyes, M., Schoeman, D.S., Rykaczewski, R.R., Thompson, S.A., Black, B.A., Bograd, S.J. 2014. Climate change and wind intensification in coastal upwelling ecosystems. Science $345,77-80$ 
1105 Taylor, A.G., Landry, M.R., Selph, K.E., Wokuluk, J.J. 2015. Temporal and spatial patterns of microbial community biomass and composition in the Southern California Current Ecosystem. Deep-Sea Res. II 112, 117-128

1108 Thunell, R.C., Pilskaln, C.H., Tappa, E., Sautter, L.R. 1994. Temporal variability in sediment fluxes in the San Pedro Basin, southern California bight. Cont. Shelf Res. 14, 333-352

Unrein, F., Massana, R., Alonso-Sáez, L., Gasol, J.M. 2007. Significant year-round effect of small mixotrophic flagellates on bacterioplankton in an oligotrophic coastal system. Limnol. Oceanogr. 52, 456-469

1113 Utermöhl, H. 1958. Zur Vervollkommung der quantitativen phytoplankton-methodik. Mitt. Int. Ver. Limnol 9, 38

Vargas, C., Contreras, P., Iriarte, J. 2012. Relative importance of phototrophic, heterotrophic, and mixotrophic nanoflagellates in the microbial food web of a river-influenced coastal upwelling area. Aq. Microb. Ecol. 65, 233-248

1118 Veldhuis, M.J.W., Kraay, G.W., van Bleijswijk, J.D.L., Baars, M.A. 1997. Seasonal and spatial 1119 variability in phytoplankton biomass, productivity and growth in the norhtwestern Indian Ocean: the southwest and northeast monsoon, 1992-1993. Deep-Sea Res. 44, 425-449

1121 Wiebe, P.H., Boyd, S., Cox, J.L. 1975. Relationships between zooplankton displacement volume, wet weight, dry weight,and carbon. Fishery Bulletin 73, 777-786

1123 Williams, P.J.1.B., Quay, P.D., Westberry, T.K., Behrenfeld, M.J. 2013. The oligotrophic ocean 1124 is autotrophic*. Ann. Rev. Mar. Sci. 5, 535-549

1125 Worden, A.Z., Nolan, J.K., Palenik, B. 2004. Assessing the dynamics and ecology of marine picophytoplankton: the importance of the eukaryotic component. Limnol. Oceanogr. 49, $168-179$ 


\section{Figure Legends}

1131 Fig. 1. Location of the San Pedro Ocean Time-series site off the coast of southern California, 1132 USA.

1134 Fig. 2. Vertical profiles of chemical and physical parameters in the top $500 \mathrm{~m}$ at the San Pedro 1135 Ocean Time-series sampling site: (a) temperature; (b) dissolved oxygen; (c) nitrate 1136 concentration; (d) nitrite concentration; (e) phosphate concentration; (f) silicate concentration. 1137 Representative profiles from four seasons are shown. Insets show expanded data in the top 100 $1138 \mathrm{~m}$ of the water column.

1140 Fig. 3. Mixed layer depths measured at $5 \mathrm{~m}$ and at the depth of the subsurface chlorophyll 1141 maximum (SCM), at the site of the San Pedro Ocean Time-series.

1143 Fig. 4. Chlorophyll $a$ concentrations measured at $5 \mathrm{~m}$ and at the depth of the subsurface

1144 chlorophyll maximum (SCM), at the site of the San Pedro Ocean Time-series.

1146 Fig. 5. Contributions of the various microbial assemblages (as percent of total microbial carbon)

1147 to depth-integrated microbial biomass at 0-100 $\mathrm{m}$ (a) and 0-500 $\mathrm{m}$ (b) at the San Pedro Ocean

1148 Time-series site. (c) Total depth-integrated organic carbon $\left(\mu \mathrm{g} \mathrm{C} \mathrm{m}{ }^{-2}\right)$ summed across all

1149 microbial assemblages for 0-100 and 0-500 m.

1151 Fig. 6. Scatter plot of carbon contained in phototrophic microbes relative to the chlorophyll $a$ 1152 concentrations in those samples for all samples collected throughout the 3-year time series at $5 \mathrm{~m}$ 1153 (solid circles) and at the depth of the subsurface chlorophyll maximum (SCM; open circles).

1154 Carbon in the phototrophic microbes was obtained by summing the carbon content estimated for 1155 the Synechococcus, Prochlorococcus, phototrophic picoeukaryote, phototrophic/mixotrophic 1156 nanoplankton, and microplanktonic phototroph assemblages. 
1158 Fig. 7. Three-year average of the distribution of carbon $\left(\mu \mathrm{g} \mathrm{C}^{-1}\right)$ contained in various microbial 1159 assemblages at $5 \mathrm{~m}$, the depth of the subsurface chlorophyll maximum (SCM), $150 \mathrm{~m}$ and $500 \mathrm{~m}$ 1160 at the site of the San Pedro Ocean Time-series.

1162 Fig. 8. Seasonal averages in the distribution of carbon $\left(\mu \mathrm{C} \mathrm{C}^{-1}\right)$ contained in various microbial 1163 assemblages at $5 \mathrm{~m}$, the depth of the subsurface chlorophyll maximum (SCM), $150 \mathrm{~m}$ and $500 \mathrm{~m}$ 1164 at the site of the San Pedro Ocean Time-series. Data were averaged for each season across the 31165 year time series for (a) winter, (b) spring, (c) summer and (d) fall.

1167 Fig. 9. Monthly averages in the distribution of carbon among the various microbial assemblages 1168 throughout the 3-year time series at the San Pedro Ocean Time-series site. Organic carbon ( $\mu \mathrm{g} \mathrm{C}$ $1169 \mathrm{l}^{-1}$ ) estimated at $5 \mathrm{~m}$ (a) and the depth of the subsurface chlorophyll maximum (SCM (b). Depth1170 integrated carbon $\left(\mu \mathrm{g} \mathrm{C} \mathrm{m}^{-2}\right)$ for 0-100 $\mathrm{m}(\mathrm{c})$ and 0-500 $\mathrm{m}(\mathrm{d})$.

1172 Fig. 10. Seasonal averages in the distribution of carbon among the various microbial

1173 assemblages throughout the 3-year time series at the San Pedro Ocean Time-series site. Organic

1174 carbon $\left(\mu \mathrm{g} \mathrm{C}^{-1}\right)$ estimated at $5 \mathrm{~m}$ (a) and the depth of the subsurface chlorophyll maximum

1175 (SCM (b). Depth-integrated carbon $\left(\mu \mathrm{g} \mathrm{C} \mathrm{m}^{-2}\right.$ ) for 0-100 $\mathrm{m}$ (c) and 0-500 $\mathrm{m}(\mathrm{d})$.

1177 Fig. 11. Monthly averages of mesozooplankton biomass $\left(\mu \mathrm{g} \mathrm{C}^{-1}\right)$ over a 2-year period (a), and 1178 comparison of mesozooplankton biomass to bacterial (phototrophic and heterotrophic 1179 assemblages) and protistan (all protistan compartments) at the San Pedro Ocean Time-series site 1180 (b). 
Table 1. Carbon conversion factors used in this study for each planktonic assemblage.

\begin{tabular}{|c|c|c|c|}
\hline Component & Values & Descriptor & Reference \\
\hline Viruses & $0.2{\text { fg } C \text { virus }^{-1}}^{-1}$ & Determined empirically & $\begin{array}{l}\text { Kepner et al. (1998) } \\
\text { Suttle (2005) }\end{array}$ \\
\hline Bacteria & $15 \mathrm{fg} \mathrm{C}$ cell $^{-1}$ & Sargasso Sea, oceanic & Caron et al. (1995) \\
\hline Synechococcus & $200 \mathrm{fg} \mathrm{C}$ cell $^{-1}$ & Sargasso Sea, oceanic & Caron et al. (1995) \\
\hline Prochlorococcus & $90 \mathrm{fg} \mathrm{C}$ cell $^{-1}$ & $\begin{array}{l}\text { S. California, coastal } \\
\text { Sargasso Sea, oceanic }\end{array}$ & $\begin{array}{l}\text { Martiny et al. (2016) } \\
\text { Casey et al. (2013) }\end{array}$ \\
\hline Picoeukaryotes & $\begin{array}{l}183 \mathrm{fg} \mathrm{C} \mu \mathrm{m}^{-3}, \\
\text { assumes average } \\
\text { radius of } 1 \mu \mathrm{m}\end{array}$ & Sargasso Sea, oceanic & Caron et al. (1995) \\
\hline Nanoflagellates & $\begin{array}{l}183 \mathrm{fg} \mathrm{C} \mu \mathrm{m}^{-3}, \\
\text { assumes average } \\
\text { radius of } 1.5 \mu \mathrm{m}\end{array}$ & Sargasso Sea, oceanic & Caron et al. (1995) \\
\hline Microplankton & $138 \mathrm{pg} \mathrm{C}$ cell $^{-1}$ & Sargasso Sea, oceanic & Caron et al. (1995) \\
\hline Mesozooplankton & $21 \mathrm{mg} \mathrm{C} \mathrm{cm}^{-3}$ & $\begin{array}{l}\text { NW Spain, coastal (based } \\
\text { on displacement volume) }\end{array}$ & Bode et al. (1998) \\
\hline
\end{tabular}


Table 2. Mean annual cell abundances at each depth for the major microbial groups observed at the site of the San Pedro Ocean Time-series. Abundances are averages \pm 1 standard deviation, and overall ranges (cells $\mathrm{ml}^{-1}$ ) for all samples from the three-year time series. Headings indicate viruses (VIRUS), heterotrophic bacteria + archaea (BACT), Synechococcus (SYN), Prochlorococcus (PRO), picoplanktonic phototrophic eukaryotes (PEUK), phototrophic/mixotrophic nanoplankton (P/MNANO), heterotrophic nanoplankton (HNANO), ciliates (CIL), dinoflagellates (DINO) and diatoms (DIAT).

\begin{tabular}{|c|c|c|c|c|c|c|c|c|c|c|}
\hline Cells $m l^{-1}$ & $\begin{array}{c}\text { VIRUS } \\
10^{7} \\
\end{array}$ & $\begin{array}{c}\text { BACT } \\
10^{6} \\
\end{array}$ & $\begin{array}{c}\text { SYN } \\
10^{4} \\
\end{array}$ & $\begin{array}{c}\text { PRO } \\
10^{4} \\
\end{array}$ & $\begin{array}{c}\text { PEUK } \\
10^{3} \\
\end{array}$ & $\begin{array}{c}\text { P/MNANO } \\
10^{3} \\
\end{array}$ & $\begin{array}{c}\text { HNANO } \\
10^{3} \\
\end{array}$ & CIL & DINO & DIAT \\
\hline \multicolumn{11}{|l|}{$5 \mathrm{~m}$} \\
\hline $\bar{x}( \pm s)$ & $2.6( \pm 2.0)$ & $1.5( \pm 0.98)$ & $2.3( \pm 2.2)$ & $1.5( \pm 1.6)$ & $9.3( \pm 15)$ & $0.76( \pm 0.67)$ & $3.1( \pm 3.7)$ & $6.3( \pm 5.8)$ & $8.2( \pm 6.4)$ & $43( \pm 51)$ \\
\hline Range & $0.32-10$ & $0.36-4.1$ & $0.17-9.2$ & $0.0081-6.9$ & $0.055-74$ & $0-2.4$ & $0.70-22$ & $0-27$ & $0-30$ & $0-210$ \\
\hline \multicolumn{11}{|l|}{ SCM } \\
\hline $\bar{x}( \pm s)$ & $2.3( \pm 1.8)$ & $1.5( \pm 0.82)$ & $2.7( \pm 3.6)$ & $1.3( \pm 1.7)$ & $9.8( \pm 10)$ & $1.2( \pm 0.83)$ & $2.3( \pm 1.7)$ & $9.8( \pm 8.8)$ & $11( \pm 10)$ & $32( \pm 32)$ \\
\hline Range & $0.26-10$ & $0.38-3.8$ & $0.20-12.9$ & $0.077-8.3$ & $2.1-38$ & $0.14-3.4$ & $0.34-7.9$ & $0.8-40$ & $0-36$ & $0.8-120$ \\
\hline \multicolumn{11}{|l|}{$150 \mathrm{~m}$} \\
\hline $\bar{x}( \pm s)$ & $0.45( \pm 0.25)$ & $0.32( \pm 0.16)$ & $0.011( \pm 0.062)$ & $0.023( \pm 0.023)$ & $0.079( \pm 0.072)$ & $\begin{array}{c}0.00017 \\
( \pm 0.00090)\end{array}$ & $0.10( \pm 0.043)$ & $0.55( \pm 0.45)$ & $3.5( \pm 5.9)$ & $17( \pm 26)$ \\
\hline Range & $0.038-1.2$ & $0.12-0.90$ & $0.0030-0.026$ & $0-0.11$ & $0.006-0.39$ & $0-0.0050$ & $0.024-0.19$ & $0-1.5$ & $0-25$ & $0.5-100$ \\
\hline \multicolumn{11}{|l|}{$500 \mathrm{~m}$} \\
\hline $\bar{x}( \pm s)$ & $0.22( \pm 0.08)$ & $0.19( \pm 0.067)$ & $0.0064( \pm 0.054)$ & $0.021( \pm 0.021)$ & $0.036( \pm 0.029)$ & $0( \pm 0)$ & $0.069( \pm 0.036)$ & $0.21( \pm 0.28)$ & $3.0( \pm 5.7)$ & $20( \pm 35)$ \\
\hline Range & $0.090-0.42$ & $0.074-.33$ & $0.00050-0.028$ & $0-0.071$ & $0-0.11$ & $0-0$ & $0.029-0.18$ & $0-0.90$ & $0-26$ & $0-190$ \\
\hline
\end{tabular}




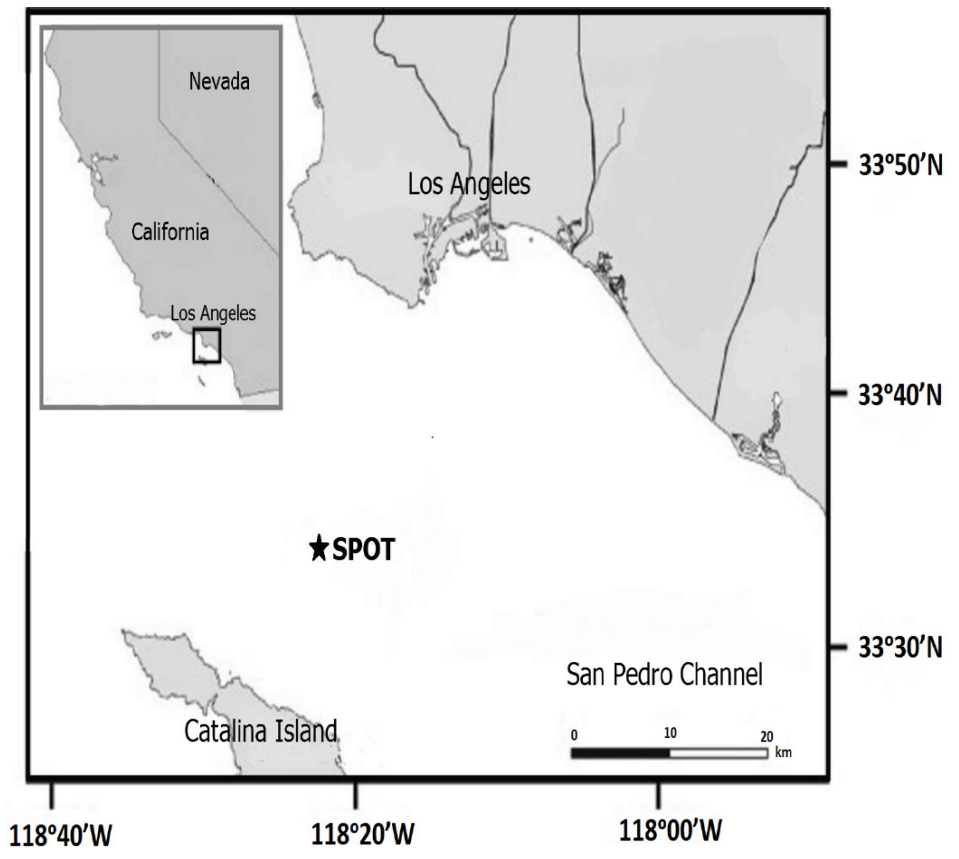

Figure 1. 

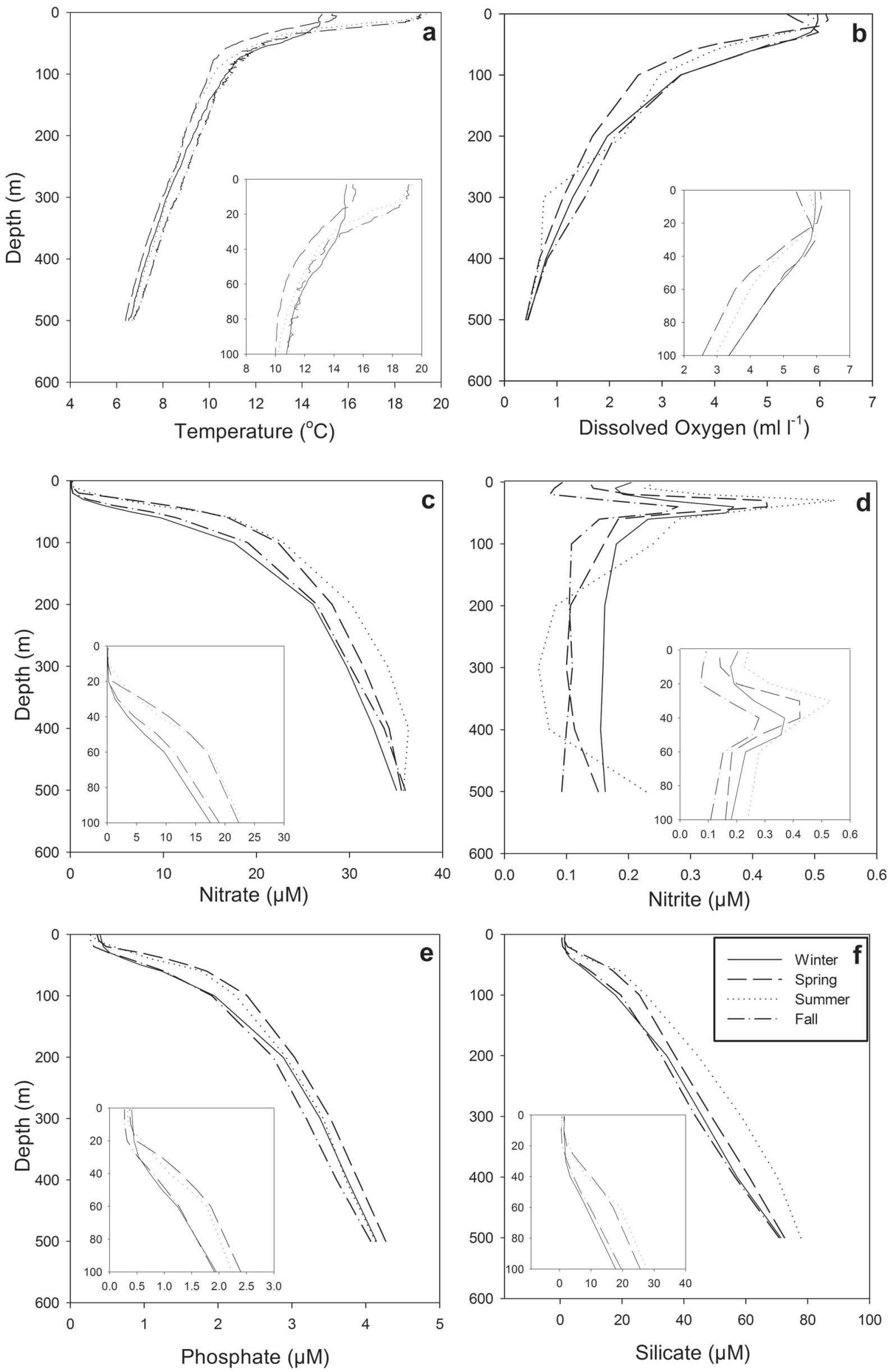

Figure 2. 


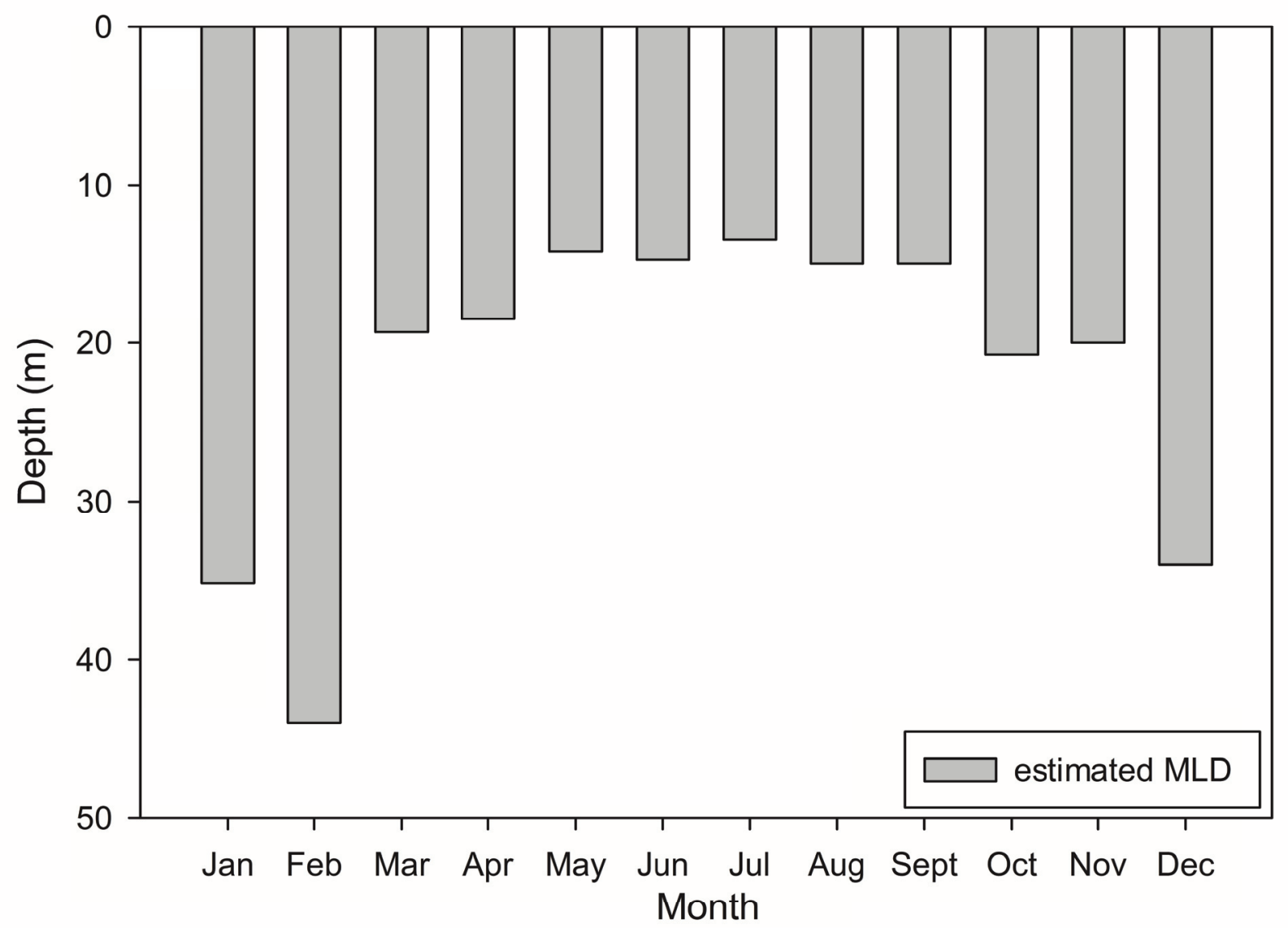

Figure 3 
Figure 4

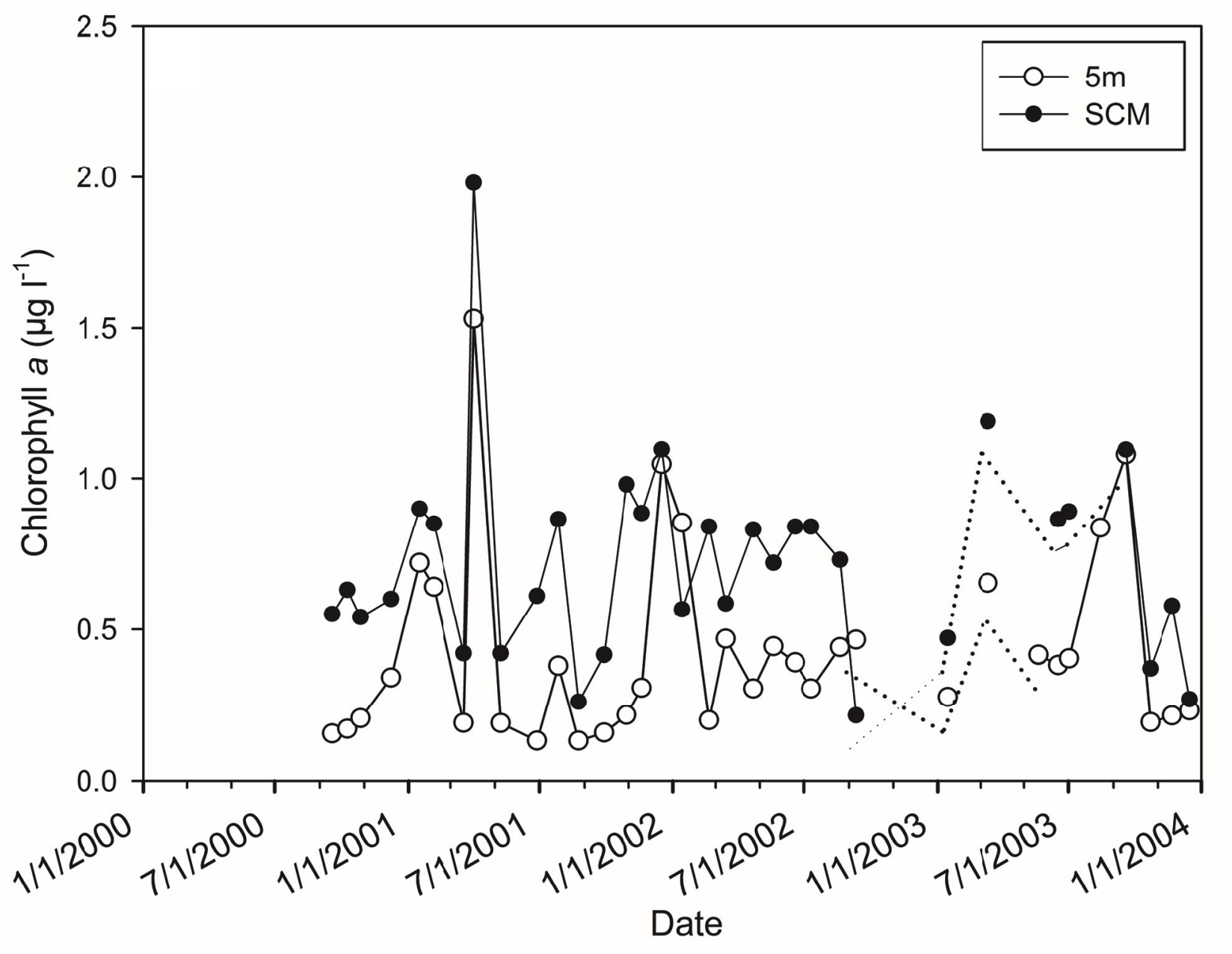



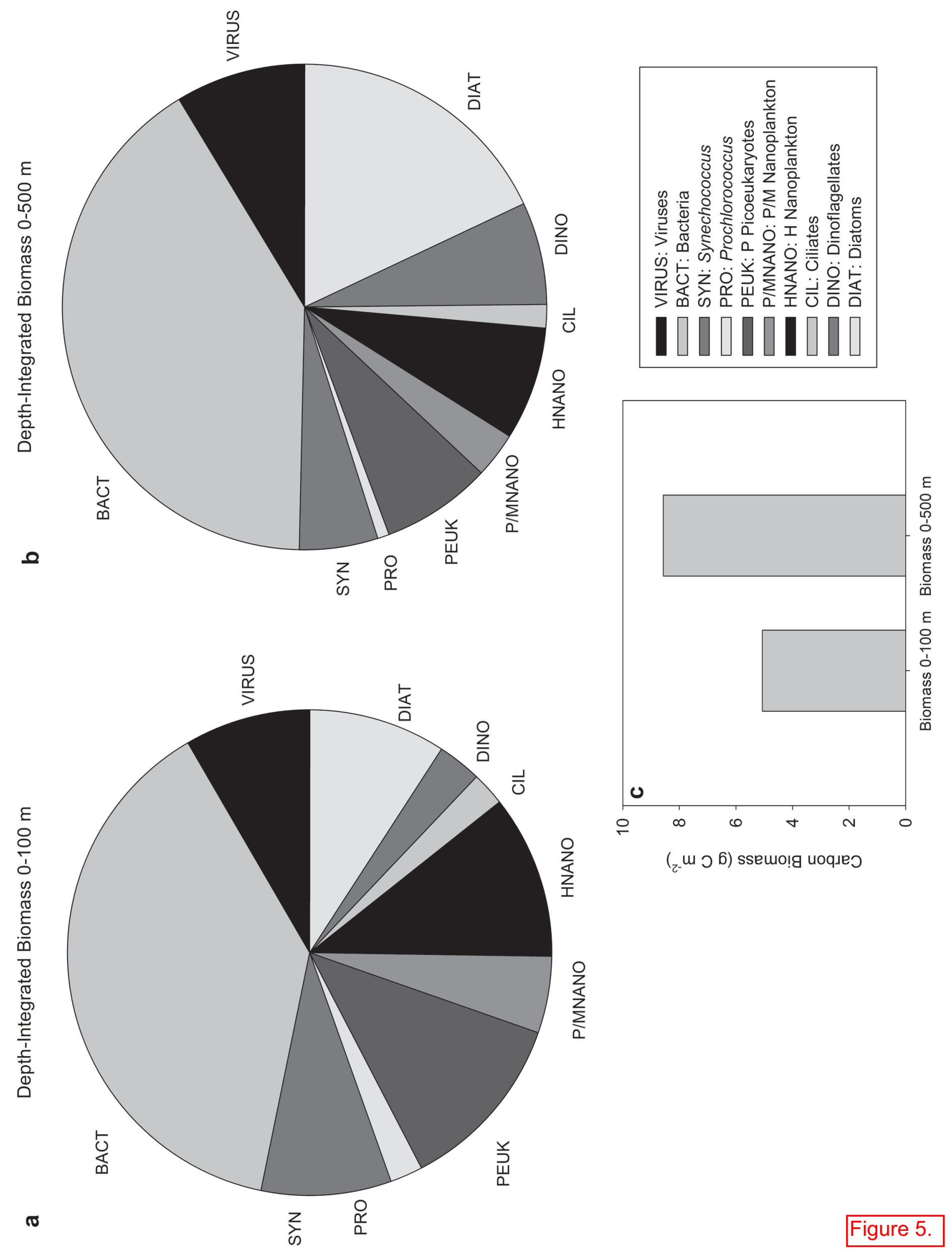


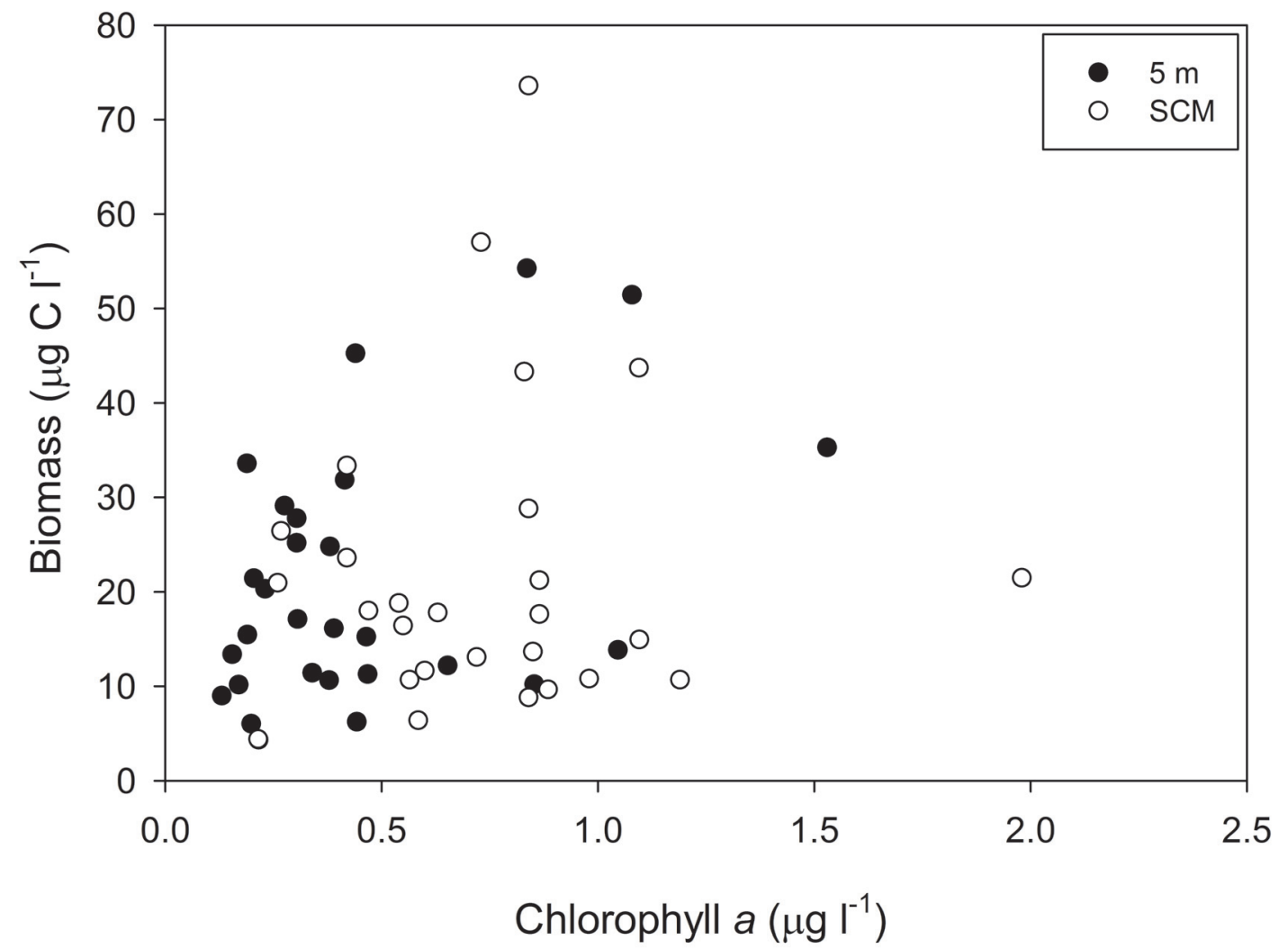

Figure 6. 


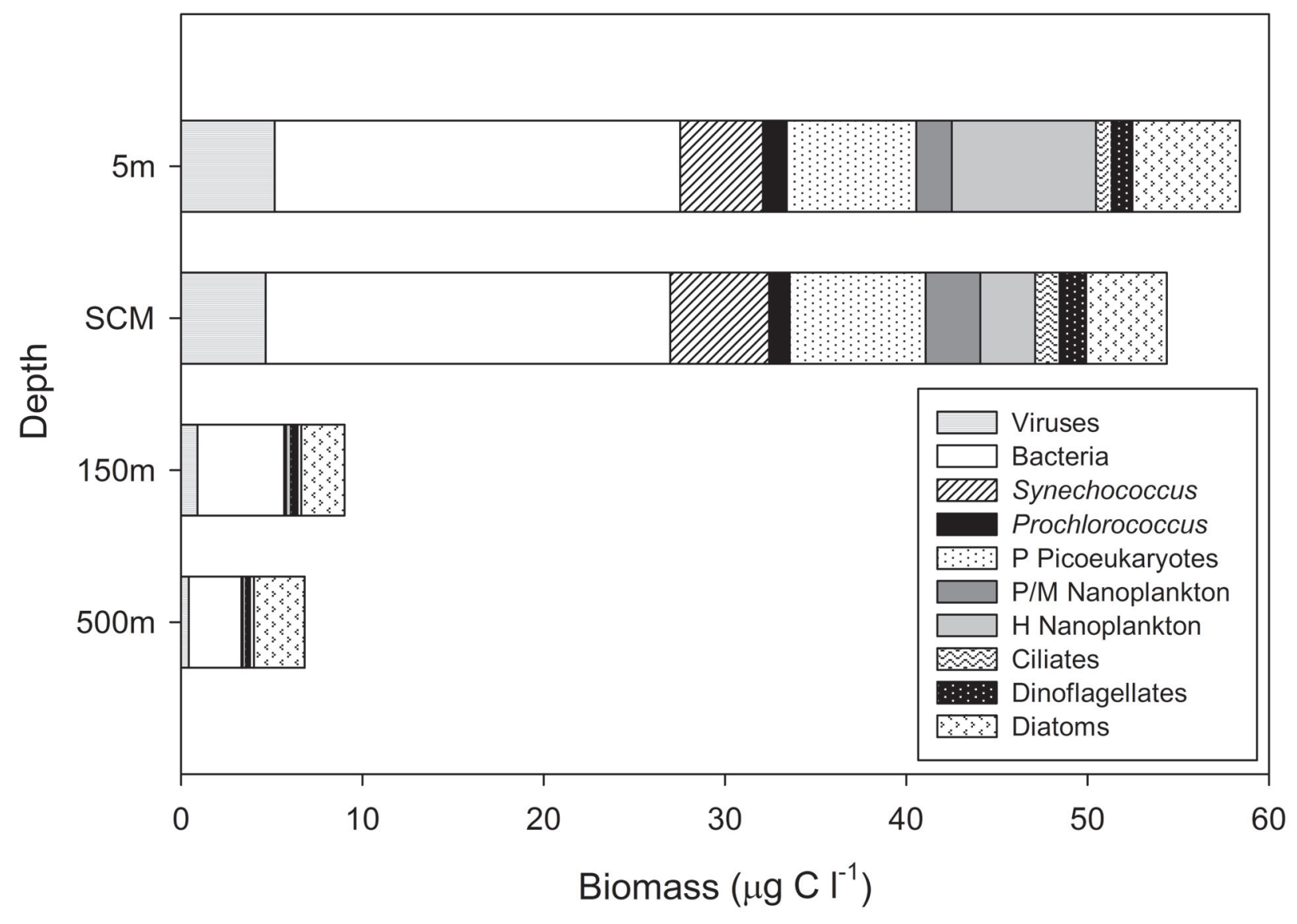

Figure 7. 

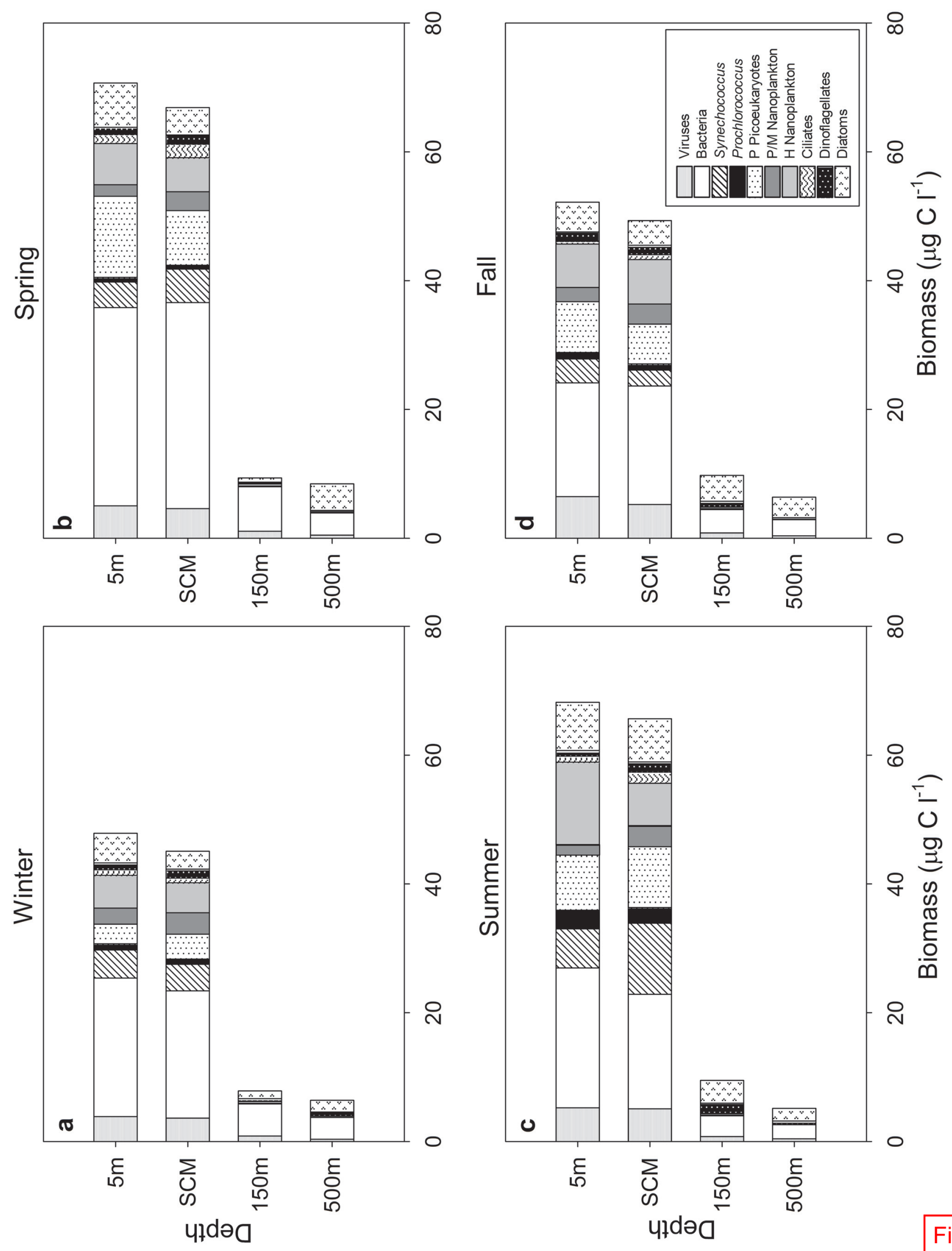

Figure 8. 

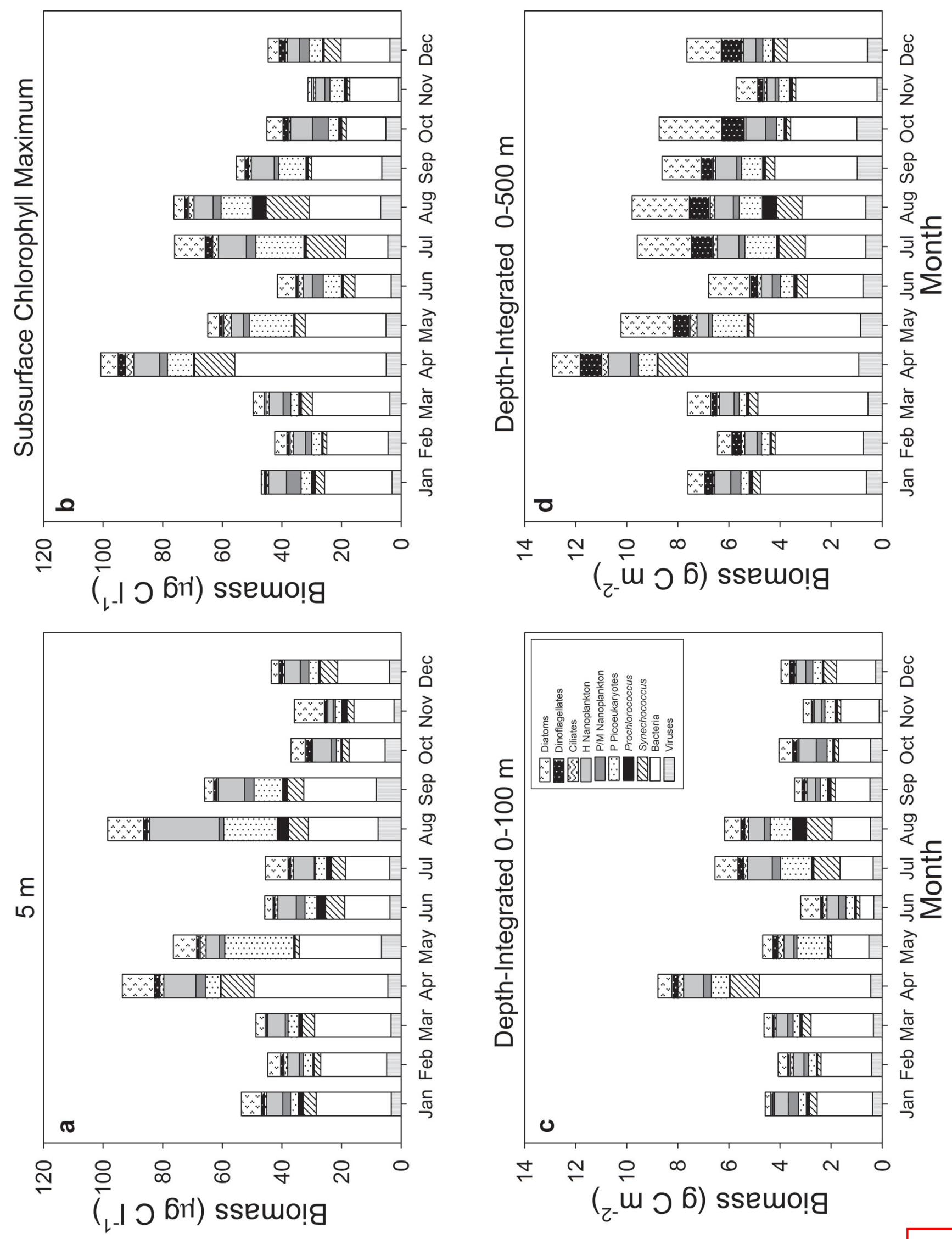

Figure 9. 

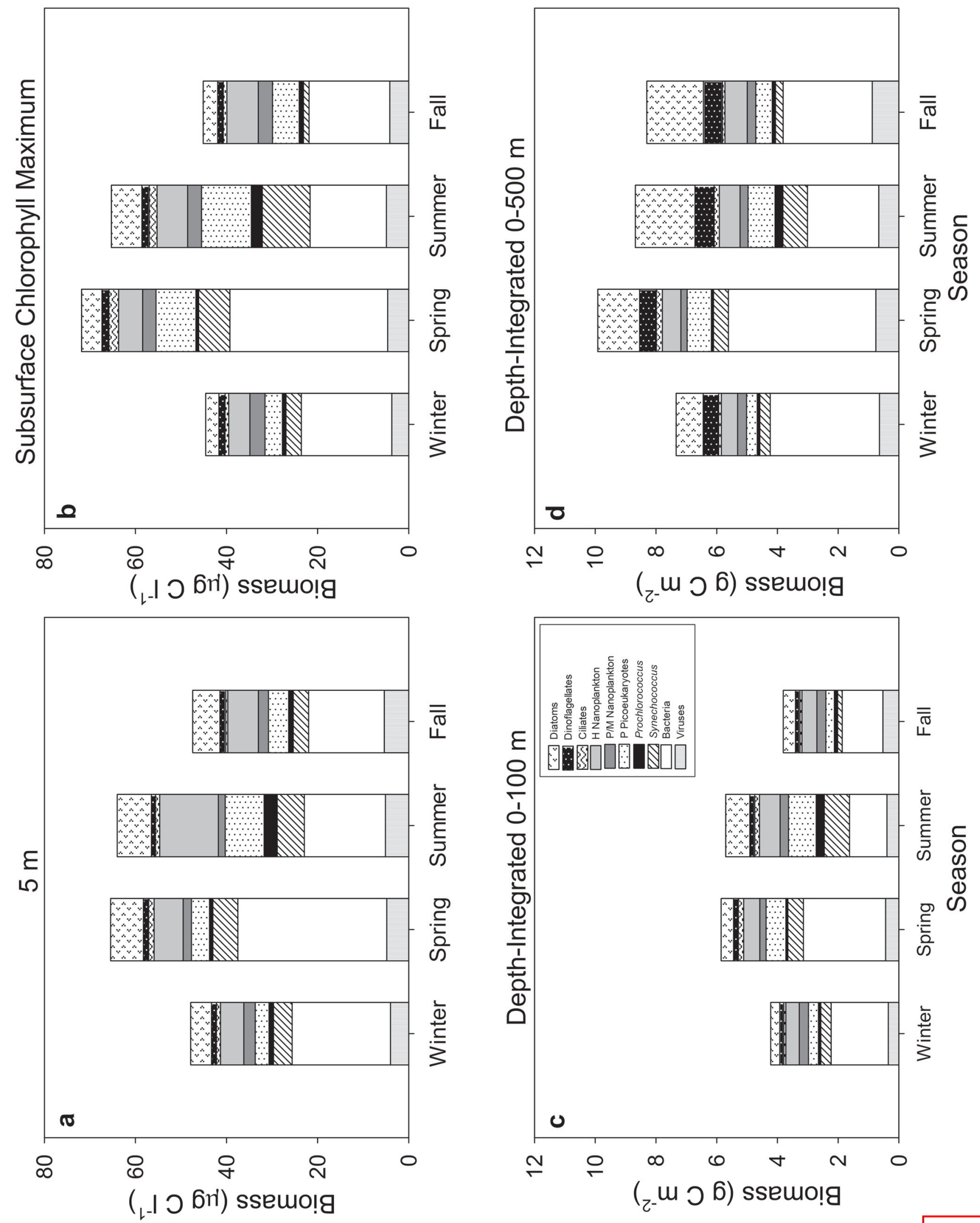

Figure 10. 

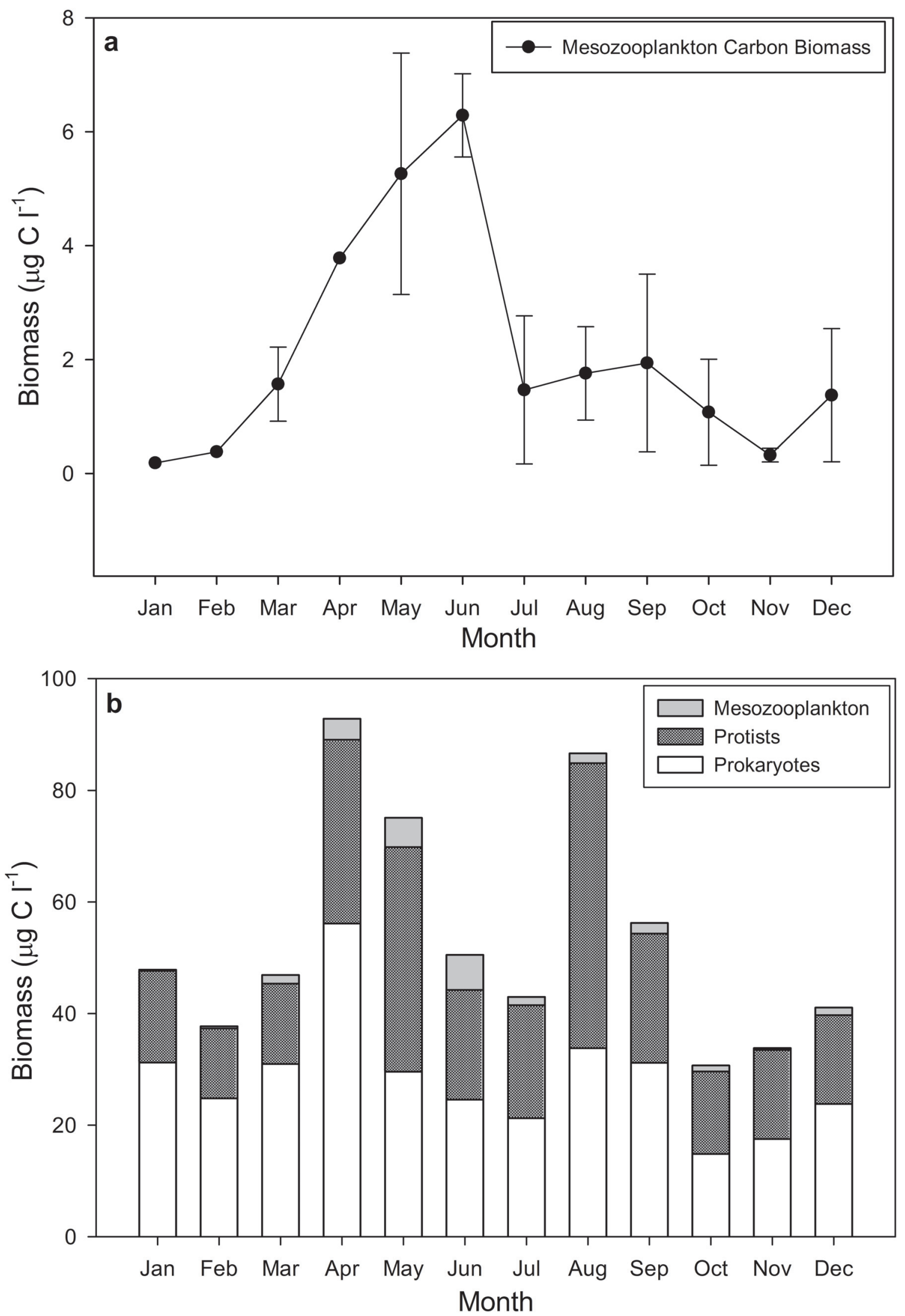

Figure 11. 